\title{
WOMEN AND JEWS IN A PRIVATE NERVOUS CLINIC IN LATE NINETEENTH-CENTURY VIENNA
}

\author{
by
}

\author{
EDWARD SHORTER *
}

On 29 October 1889, Mathilde S., an unmarried artist of twenty-seven, was admitted to Wilhelm Svetlin's private nervous clinic in Vienna. A young Jewish woman, she had always been "very impressionable" and had a history of headaches. In 1886 she had become engaged to a man of "weak character", and even though the relationship had ostensibly remained platonic, she found herself in a highly excitable sexual state. Six months after the engagement began, however, she fell into something of a depression, "with hysterical facial changes". As a result of this her fiancé abandoned the engagement. Three months later she learned that he had become engaged to someone else. She thereupon flipped into maniacal excitement, began planning a "brilliant career" and engaged in "risky business contracts", rejecting the advice of relatives. Whatever later generations of women might say about this behaviour, it was considered at the time evidence of "mania", and it was for the mania that her father placed her in Svetlin's clinic. ${ }^{1}$

The admitting physician was listed as "Herr Dr. Freud". Mathilde is a previously unknown case of Freud's, and it is of interest that, in the words of the clinic's staff, "she had made a whole cult out of worshipping her doctor, who had treated her with hypnosis during her depressed phase." In admitting Mathilde S. for "mania gravis" to

*Edward Shorter, Ph.D., Department of History, University of Toronto, Toronto, Ont. M5S 1A1, Canada.

For their criticisms of an earlier draft I should like to thank Prof. Dr Eberhard Gabriel, MD, Prof. Jacques Kornberg, Prof. Michael Marrus, Dr Harold Merskey, MD, Dr Rainer Münz, Dr Roy Porter, Prof. Joseph Shatzmiller, Dr Anne Marie Shorter, MD, and Prof. Dr Reinhard Spree. I am also grateful to two anonymous critics for their careful comments.

\footnotetext{
${ }^{1}$ The case of Mathilde S. is no. 361 of the Haupt-Protokoll book, 1879-1891, of the Privat-Heilanstalt Svetlin, preserved in the Wiener Stadt- und Landesarchiv, in the Rathaus of Vienna, shelf no. M. Abt. 209. This register of admissions to the clinic includes the patient's name, religion, age, birthplace, occupation, and referring physician, as well as information on the medico-legal aspects of committal to this private psychiatric hospital. It has 508 entries on 468 separate patients, some patients having been admitted more than once. Although the register contains no case histories as such, selected case histories of patients in the Svetlin clinic, identified only by initial, were published by Hanns Kaan, an assistant doctor in the clinic, as an article in a book edited by Wilhelm Svetlin, Zweiter Bericht über die Privatheilanstalt für Gemüthskranke auf dem Erdberge zu Wien, Vienna, 1891, pp. $99 \mathrm{ff}$. The case of Mathilde S. is on pp. 142-3. It was possible to identify the case history in the published volume as that of Freud's patient because Kaan used the patient's correct initials and ages. Further case histories from this clinic may be found in Kaan's book, Der neurasthenische Angstaffect bei Zwangsvorstellungen und der primordiale Grübelzwang, Vienna, 1892. Some additional manuscript case histories from the Svetlin clinic, beyond 1891, have been preserved in the archive of the Psychiatrisches Krankenhaus der Stadt Wien, and I am indebted to Prof. Dr Eberhard Gabriel for granting me access to them. The remainder of the Svetlin clinic's archive, housed at the Psychiatrisches Krankenhaus der Stadt Wien, has unfortunately been destroyed.
} 
a private nervous clinic, Freud thus found himself at the centre of the whole world of nervous diseases, treated in exclusive private hospitals for the middle- and upper classes.

The purpose of this paper is, first to examine these private nervous clinics of Central Europe in the second half of the nineteenth century, as they are a relatively unstudied context for the setting of psychiatric and neurological illness, and second, to analyse the population of one such clinic in Vienna in the 1880s and 90s, the Svetlin clinic where Mathilde S. was hospitalized, paying special attention to its female and Jewish patients.

Why Jews and women became objects of particular curiosity in neurology and psychiatry in the nineteenth century has not been satisfactorily explained. The doctors of the time believed both groups specially liable to disease: Jews because of hereditary weakness resulting from inbreeding, and women because of an inborn lability of the nervous system. Subsequent historians have been inclined to reduce the whole question to a matter of "labelling". A dominant male society wished to subdue the rising aspirations of both women and Jews by "labelling" them mentally ill. Thus, for example, Sander Gilman has recently addressed the "myth of the mental illness of the Jews". He writes that "Jews, like women, [were thought to possess] a basic biological predisposition to specific forms of mental illness. Thus [both groups] could be dismissed as unworthy of becoming part of the privileged group because of their aberration."2

Against this labelling hypothesis, others have argued that psychiatric and neurological disease is a very real phenomenon, not just a matter of one group branding another group "ill" so as better to control its members. Some of the evidence discussed in this paper suggests that, historically, men and women, and Jews and non-Jews, have been subject to different patterns of diseases of the mind and nervous system. Understanding these differences means coming to grips with the complex interaction between culture and biology, rather than merely dismissing biology.

THE SETTING: THE RISING TIDE OF NERVOUS DISEASE

One of the categories of "nervous disease" is formal psychiatric illness, disorders thought in the nineteenth century to require confinement of some kind. The number of patients committed to insane asylums with diagnoses of mental illness increased everywhere in the course of the century. In Prussia, for example, the number of patients in public asylums rose from 14,500 in 1875 to 59,000 in 1900 , the number of public asylums themselves climbing from 46 to $104 .^{3}$ In 1852 in Prussia, one person for every

\footnotetext{
${ }^{2}$ Sander L. Gilman, 'Jews and mental illness: medical metaphors, anti-Semitism, and the Jewish response', J. Hist. behav. Sci. 1984, 20: pp. 150-9, quotes from p. 157.

${ }^{3}$ [Hermann] Grunau, Ueber Frequenz, Heilerfolge und Sterblichkeit in den öffentlichen preussischen Irrenanstalten von 1875 bis 1900, Halle a. S., 1905, p. 5. Recently identified with this interpretation is Michel Foucault, Madness and civilization: a history of insanity in the Age of Reason (1961), Eng. trans., Richard Howard, New York, Random House, 1975, see chs. 8 and 9. Andrew T. Scull has attempted to apply this hypothesis to England: Museums of madness: the social organization of insanity in nineteenth-century England, London, Allen Lane, 1979. As for Germany, Dirk Blasius has seen the rise of the asylum as characteristic of a certain stage of "social development", in which the police and courts use the asylum for the repression of unsanctioned behaviour. Blasius, Umgang mit Unheilbarem: Studien zur Sozialgeschichte der Psychiatrie, Bonn, Psychiatrie Verlag, 1986, pp. 62-3 and passim.
} 


\section{A private nervous clinic in late nineteenth-century Vienna}

5,300 in the population was confined in an asylum, by 1911 one in every 500. In Austria it was one in every 6,900 in 1852 , one per 1,000 population by 1911 . In Switzerland, asylum admissions doubled between 1890 and $1911 .^{4}$

Why this tremendous spurt in asylum admissions? More mental illness? One group of students sees the increase as the result of shifting the poor and unmotivated from such institutions as gaols and workhouses to insane asylums, where instead of being thought merely lazy and criminal, they would now be defined as "insane". Hermann Grunau, a distinguished contemporary writer on asylums, pointed out in 1905 that in Prussia many insane individuals were removed from gaols, or sentenced to an asylum rather than to gaol. Insane vagabonds were now being confined rather than left to beg on the streets. ${ }^{5}$ Thus, part of the increase was clearly the result of putting in mental hospitals new groups of individuals, people who previously had been left alone or were cared for in other institutions. Yet over the same period the number of patients in private asylums increased sharply as well. As table 1 shows, in 1852 in Germanspeaking Europe there were only 320 mental patients in 21 private asylums. No separate clinics for nervous patients existed at this point. By 1880, 2,700 mental and nervous patients were hospitalized in 81 profit-making asylums and clinics. By 1906 the notion of the "private insane asylum" had given way almost entirely to the private nervous clinic. In 1906 there were 8,500 patients in some 140 profit-making clinics.

Table 1: THE NUMBER OF PATIENTS IN PRIVATE NERVOUS CLINICS IN CENTRAL EUROPE, 1852-1906

\begin{tabular}{|c|c|c|c|c|}
\hline \multirow[t]{2}{*}{ Year } & \multicolumn{2}{|c|}{ Number of clinics } & \multicolumn{2}{|c|}{ Number of patients } \\
\hline & Profit-making & Charitable & $\begin{array}{l}\text { In profit-making } \\
\text { clinics }\end{array}$ & $\begin{array}{l}\text { In charitable } \\
\text { clinics }\end{array}$ \\
\hline $\begin{array}{l}1852^{*} \\
1880^{* *} \\
1906^{* * *}\end{array}$ & $\begin{array}{r}81 \\
139\end{array}$ & $\begin{array}{l}16 \\
30\end{array}$ & $\begin{array}{l}2,700 \\
8,500\end{array}$ & $\begin{array}{l}1,200 \\
8,000\end{array}$ \\
\hline
\end{tabular}

*1852: Heinrich Laehr, Ueber Irrsein und Irrenanstalten (Halle, 1852), p. 229 for the figures " 21 " and " 320 ", which include both profit-making and charitable institutions.

** 1880: Heinrich Laehr, Die Heil- und Pflegeanstalten für Psychisch-Kranke des deutschen Sprachgebietes (Berlin, 1882), from his city-by-city tabulation of all institutions occupied with nervous disease. I included only institutions listed as "Private Heil- und Pflegeanstalten für Psychisch-Kranke" and (private) "Offene Kuranstalten". "Wasserheilanstalten" and "Pflegeanstalten" for incurables have been omitted. The clinics generally sent in current-occupancy figures for 1880 or 1881 . A variety of institutions were classed as "charitable", from those run by benevolent private corporations to those established by the Protestant and Catholic churches.

***1906: Hans Laehr, Die Anstalten für Psychisch-Kranke in Deutschland, Deutsch-Österreich, der Schweiz und den baltischen Ländern, 6th ed., (Berlin, 1907), from his city-by-city tabulations. I included only institutions listed as "Privat-Anstalten für Psychisch-Kranke" and as "Privat-Anstalten für Nervenkranke". Again, "Wasserheilanstalten" and nursing homes for incurables have been omitted. Returns generally for occupancy in 1906.

Thus the increase in numbers of well-to-do mental and nervous patients kept pace with that of patients in public asylums. It is difficult to contrast them exactly because public institutions admitted patients from well-defined catchment areas, while the private clinics recruited them from all across Europe and Britain. Patients in the Svetlin

\footnotetext{
${ }^{4}$ Hans Laehr, Die Anstalten für Psychisch-Kranke in Deutschland, Österreich, der Schweiz und den baltischen Ländern, 7th ed., Berlin, 1912, p. 245. After 1864 these statistics include patients in private clinics, and encompass the mentally-retarded and epileptics, as well as the "Psychisch-Kranke".

${ }^{5}$ Grunau, op. cit., note 3 above, pp. 6-7.
} 


\section{Edward Shorter}

clinic came from cities as wide apart as Athens and New York. The point is that we may not explain the rise in numbers of private nervous patients as a result of emptying out the gaols and workhouses and tidying up the vagabonds. It was not a consequence of changing institutional arrangements. Patients in these private clinics had either been free of disease before, or they had been cared for at home.

To understand the rise in numbers of private nervous patients, we must first break this vague concept of "nervous disease" into its component parts. Each seems to have become substantially more common during the nineteenth century. As we see things today, ${ }^{6}$ what the nineteenth century called "nervous disease" is in fact composed of:

(a) organic diseases of the nervous system, for example neurosyphilis or alcoholic hallucinations. Here the substance of the brain is affected by an invading microorganism or a toxic chemical. Nineteenth-century writers, it must be pointed out, deemed neurosyphilis a "mental illness", rather than a neurological or medical illness, because of the patients' frequent psychoses. And the most common variant of neurosyphilis, "dementia paralytica", was treated in insane asylums as a "disease of mind".

(b) major psychiatric disorders, i.e. hallucinations, delusions, and illusions without an obvious organic cause; it also means such thought disorders as manifested by the non-sequiturs of schizophrenia, and the mood disorders of major depressions and manic-depressive illness. All of the above are loosely called psychoses. In the nineteenth century these psychoses represented the proper terrain of psychiatry. Psychiatrists distinguished roughly between diseases of the mind ("Geisteskrankheiten") and organic disorders of the nervous system ("Nervenkrankheiten"), although many believed that "mind disease" was just a kind of brain disease without obvious lesions.

(c) the psychoneuroses involving lesser, "neurotic" disturbances of functioning such as hysteria, hypochondria, and mild depression. Opinion today is divided as to whether these arise from unconscious attempts to protect against anxiety, as Freud believed, or whether these psychoneuroses have deep biological roots.

The incidence of these varieties of nervous disease - organic brain disease, formal psychiatric illness, and the psychoneuroses-seems to have increased during the nineteenth century.

Neurosyphilis, or spirochetosis of central nervous tissue, was the most common variety of organic brain disease treated in these clinics. Although syphilis itself had been present in Europe since at least the fifteenth century, only around the time of the Napoleonic Wars did the disease's final (tertiary) stages seem to have begun to involve the nervous system. ${ }^{7}$ By the end of the nineteenth century, around a tenth of all syphilis patients would go on to have neurosyphilis, an irreversibly fatal disease. ${ }^{8}$

\footnotetext{
${ }^{6}$ The following embodies Central European psychiatric thought as codified around the time of the First World War, and is accepted today in most places outside of France.

7 Important articles in the literature on the spread of neurosyphilis during the nineteenth century are [Otto] Mönkemöller, 'Zur Geschichte der progressiven Paralyse', Z. ges. Neurol. Psychiat., 1911, 5: 500-89, and Edward Hare, 'The origin and spread of dementia paralytica', Br. J. Psychiat. 1959, 105: 594-626. Hare's hypothesis was that "a mutant neurotropic strain of the syphilitic spirochaete appeared in northern France [c. 1800] and then spread by venereal infection along the trade routes of the world." (p. 612).

${ }^{8}$ The classic study of what happens to untreated syphilitics is E. Gurney Clark and Niels Danbolt, 'The Oslo Study of the natural course of untreated syphilis', Med. Clins N. Am., 1964, 48: 613-23. On the irreversible nature of general paresis in the absence of treatment see Stanley L. Robbins and Ramzi S. Cotran, Pathologic basis of disease, 2nd ed., Philadelphia, W. B. Saunders, 1979, p. 1544.
} 


\section{A private nervous clinic in late nineteenth-century Vienna}

There are two forms of neurosyphilis. In one, called "meningovascular syphilis", the invading spirochete may limit itself to the brain's lining (meninges) and blood vessels. Hard to differentiate from a stroke, meningovascular syphilis was not often diagnosed except at autopsy. When the micro-organisms penetrate the substance (parenchyma) of the brain and spinal cord itself, however, a strikingly different clinical picture arises, depending on where the infection is fiercest. If the brain stem and spinal cord are primarily involved, that patient may slowly become paralysed ("progressive paralysis"), or lose sensation (tabes dorsalis, locomotor ataxia) and thus acquire a kind of foot-slapping gait. When the infection extends into the grey and white matter of the brain, the patient becomes demented in addition to being paralysed. This disorder was commonly known as "dementia paralytica".

It was dementia paralytica and progressive paralysis that became epidemic during the nineteenth century. In Prussian public asylums, for example, the number of patients with "paralytic mental disorders", most of which were probably syphilitic dementia paralytica, increased more than fivefold between 1875 amd $1900 .{ }^{9}$ Perhaps a quarter of all male patients in private nervous clinics had dementia paralytica or progressive paralysis, which indicates the quantitative importance of neurosyphilis in the increase of nervous disease.

How about psychoses, the second major category of nervous disease? Here the most important disorders are the various kinds of depression and schizophrenia. "Melancholia" is one of the most familiar afflictions in the history of psychiatry, descriptions of it reaching back to the ancient Greeks and Romans. At present it is quite impossible to say if such "major depressions", or "major affective disorders" as they are now called, have changed in frequency over the years. ${ }^{10}$

Although schizophrenia, the other important psychosis, was not clearly delineated until the beginning of the twentieth century, a retrospective study of cases does indeed suggest that it was unusual in the distant past, becoming common only in the course of the nineteenth century. E. Fuller Torrey, who has conducted the most recent survey of the literature, concludes that, "Schizophrenia appears to be of recent origin. While there were undoubtedly occasional cases of the disease in past centuries . . . its widespread distribution appears to date to the beginning of the nineteenth century." 11 What is especially intriguing in schizophrenia's apparent increase is the possibility that the disease is caused by a virus. Although this view remains highly controversial within psychiatry, several authorities have argued in its favour, and, if they are correct, the historic increase might be explained as a spreading infection. ${ }^{12}$ If schizophrenia did increase, the numerous young patients with a "primary psychosis" ("primäre

\footnotetext{
${ }^{9}$ Grunau, op. cit., note 3 above, p. 42 . Cases rose from 881 , in 1875 , to 4,634 in 1900 . Some of the dementias of the elderly also involve paralysis, and may have been put in this category too.

${ }^{10}$ Stanley W. Jackson, the most recent student of this subject, has been unable to solve this puzzle: Melancholia and depression from Hippocratic times to modern times, New Haven, Yale University Press, 1986.

${ }^{11}$ E. Fuller Torrey, Schizophrenia and civilization, New York, Jason Aronson, 1980, p. 40.

12 Here, again, the fertile mind of Edward Hare has been at work. See his 'Epidemiological evidence for a viral factor in the aetiology of the functional psychoses', in P.V. Morozov (ed.), Research on the viral hypothesis of mental disorders, Advances in Biological Psychiatry, vol. 12, Basle, Karger, 1983, pp. 52-75.
} 


\section{Edward Shorter}

Verrücktheit", meaning a psychosis without an obvious cause) and "paranoia" in these private clinics were probably among its early victims.

As for the psychoneuroses, the third great form of nervous disease, what may have happened is not so much an increase in frequency as a change in family sensitivity to these disorders, and a change in their presentation. It is quite possible that the psychoneuroses have not altered at all in frequency over the ages, that as many people were "neurotic" in the fourteenth century as in the nineteenth. What may have changed is rather the form in which neurosis is expressed. Individuals may choose to express inner distress with fits at shrines or on pilgrimages, or in clinics and doctors' offices in the medically "recognized" forms of psychoneuroses. Thus the convulsive disorders of the distant past, the writhing and screaming-out upon the road to the shrine, clearly recede in the nineteenth century. In their stead arose such new ways of representing distress as the psychogenic paralyses, which were specially common among young women in the late nineteenth and early twentieth centuries. Or we find anorexia nervosa, a disorder not uncommon at the end of the nineteenth century which has gone on to assume epidemic proportions in our own time. ${ }^{13}$

Thus the psychoneuroses may have seemed to increase in frequency because of an increase in people's disposition to define minor depression, conversion hysteria, obsessive behaviour and the like as medical "diseases" and seek help for them. As Wilhelm Svetlin, the owner of the private clinic featured in this paper, lectured his medical readers, the first step to recovery in a mental illness is defining oneself as ill. "Once the patient has convinced himself of the pathological nature of his feelings and ideas, the most essential step to complete recovery has been taken: the awareness of illness." 14

Finally, in the nineteenth century the family circle became the customary setting of the psychoneuroses, rather than the village square or the open road. Several historians have argued that the heat of this cauldron of family intimacy became intensified from the second half of the eighteenth century onwards. ${ }^{15}$ And intimacy may have brought with it a preoccupation with monitoring inner feelings and a tendency to "medicalize" internal sensations.

These propositions are speculative, but they may be witnessed in many case histories. On the first of September 1911, Anton B., twenty-one, the son of a prominent Viennese cultural figure, was admitted to the middle-class "Sanatorium" of Vienna's public psychiatric hospital, the "Steinhof". He had been living at home. His diagnosis upon admission was "neurasthenia", attributed to his inborn "neuropathic disposition" and his "sexual excesses". On examination he showed no

${ }^{13}$ On the appearance of hsyterical paralyses and anorexia nervosa in the nineteenth century, see Shorter, 'Paralysis: the rise and fall of a "hysterical" symptom', J. soc. Hist. 1986, 19: 549-82; and idem, 'The first great increase in anorexia nervosa', ibid., 1987, 21: 69-96.

${ }^{14}$ Wilhelm Svetlin, Die Privatheilanstalt für Gemüthskranke auf dem Erdberge zu Wien. Bericht, Vienna, 1884 , p. 137. On historic changes in the willingness to define symptoms as "illness", see Shorter, Bedside manners: the troubled history of doctors and patients, New York, Simon and Schuster, 1985, chs. 5 and 8.

${ }^{15}$ See, for example, Shorter, The making of the modern family, New York, Basic Books, 1975; and, more recently, Judith Schneid Lewis, In the family way: childbearing in the British aristocracy, 1760-1860, New Brunswick, N.J., Rutgers University Press, 1986, especially chs. 1 and 2. 


\section{A private nervous clinic in late nineteenth-century Vienna}

signs of a psychiatric disorder but rather was intensely preoccupied with his bodily sensations; he was also subject to panic attacks. "He has been nervous since the age of five, suffering from night terrors, and on occasion quite insane. Even an operation on his nose changed nothing." (This was the heyday of "nasal reflex neurosis", in which the interior of the nose was thought to have special physiological links with far distant body organs, including the brain.)

Recently Anton B. had been awakening at night, fearful that his heart was about to stop beating. "He concluded from a chance remark of his doctor that he has a heart defect, and since then his breathlessness on stair-climbing and his cardiac complaints have increased considerably. A cure at Nemeth-Boksany [evidently a spa] availed nothing ... and since his departure from there indeed he has undergone a complete 'collapse'. Recently a series of new sensations have further come to torture him: feelings of anxiety, of suffocation, of choking in his throat, as if a cord were being drawn about it, a feeling of something amiss [Verlegtsein] behind his ears, pressure in his head, the impression 'as though he is seeing everything very differently', as though white were much too blinding and sharper than earlier . . .". Et cetera. The list of Anton B.'s sensory complaints continues at length. He held up his hands in the clinical interview and confessed to "colossal sexual deviations", to onanism, and to "exceptionally frequent, normal sexual activity". For an entire year he had "thought enormously". He feared he had "ruined his nervous system completely and is a goner [werde dann abkratzen]". 16

One might argue that, before the middle of the eighteenth century, this pattern of complaints was unusual on the continent of Europe. Premodern family members took less of an interest in individuals' symptoms; people were less willing to define "suffocations" añd palpitations as medical conditions; and when doctors did encounter them, they did not make the diagnosis of "nervous disease", but rather of uterine disorder in women and "spleen" in men. Anton B.'s "neurasthenia" was thus typical of the psychoneuroses of the nineteenth and twentieth centuries, and his willingness to admit himself voluntarily to the Steinhof's Sanatorium suggest the sources of this third great variety of "nervous disease": family intimacy, medical suggestion, and a new kind of interior search.

\section{PRIVATE CLINICS FOR “MENTAL” AND "NERVOUS” DISEASE}

Today we see a clear difference between psychiatric diseases of the mind, and neurological affection of the brain and spinal cord. In the world of the private nervous clinic this distinction was conflated. Psychiatric and neurological diseases alike were called "nervous diseases", or "Nervenkrankheiten". How did this come about?

First of all, psychiatry and neurology did not merely develop on parallel tracks during the nineteenth century. They converged. The whole generation of psychiatrists that followed on the heels of Wilhelm Griesinger and Moritz Romberg in the 1860s

\footnotetext{
${ }^{16}$ Patient file from the Nieder-Österreichisches Landes-Sanatorium "Am Steinhof", preserved in the Psychiatrisches Krankenhaus der Stadt Wien. I have been unable to identify "Nemeth-Boksany"; "abkratzen" is Austrian slang for "die".
} 


\section{Edward Shorter}

believed that mind disease was in fact brain disease, that nothing was "psychogenic" and all was "somatogenic", meaning based on a physical affection of the tissues. ${ }^{17}$ It became an article of faith that "psychiatric" disorder stemmed from organic disarray in the substance of the brain. As Caspar Max Brosius, director of the clinic at Bendorf-Sayn on the Rhine, wrote in 1881, "Madness is a disease of the brain". He referred to "the brain disease that we call insanity", and criticized psychological treatments. "We remove psychiatric symptoms not through the counter effect of psychic and moral agencies but through rest and peace for the patient's brain." 18

This doctrine served well the economic interests of the private clinics, which before then had been little more than private insane asylums with locked wards. ${ }^{19}$ When patients with non-psychiatric "nervous" diseases previously had sought treatment at all, it was in water-therapy centres (Wasserheilanstalten) situated in hot- and cold-springs, or in private practice. Since the beginning of the nineteenth century the odium of Bedlam, of the "madhouse", had clung to private insane asylums. Well-to-do families considered them "places of horror", as Wilhelm Svetlin wrote in 1884. Svetlin continued, "Almost daily it comes to our attention that the general public has missed out completely on a whole century of humane treatment of the insane. Every psychiatrist has at one time or another been urgently requested by the patient's relatives not to chain him up or whip him." 20 When private patients did go into these early asylums, the families preferred to say it was for nervous, not psychiatric, disease. $^{21}$

The transformation from private insane asylum to private nervous clinic would occur as the result of a tacit collusion between the two parties, doctors and patients. The patients feared "the asylum"; the owners of the private clinics, who were largely psychiatrists, feared the competition of the internal-medicine clinics.

It was partly to attract patients that owners of private asylums began referring to them, not as asylums for mental illness, but as clinics for nervous disease-and for what the Germans call "Gemütskrankheiten", literally diseases of "spirit". The term "Nervenkrankheiten" in and of itself embraced, in organically-oriented medical

\footnotetext{
${ }^{17}$ Griesinger sounded one famous battle-cry in his preface to the first volume (1868) of his journal, the Archiv für Psychiatrie und Nervenkrankheiten. He wrote, "The so-called 'mental illnesses' ['Geisteskrankheiten'] affect individuals suffering from brain and nerve disease [Hirn- und Nervenkranke Individuen]." (p. iii). He further noted that the distinction between "psychoses" and "other nervous diseases" is completely artificial because outside the asylums were plenty of "individuals suffering from nervous disease, whose affective and cognitive reactions have already become quite pathological." It was a matter of indifference whether one labelled a patient "Gemütskrank" or "Nervenkrank", he wrote. In many cases it was all the same thing (p. iv). Klaus Doerner has put Griesinger in the context of German psychiatric thought in, Bürger und Irre: zur Sozialgeschichte und Wissenschaftssoziologie der Psychiatrie, Frankfurt-am-Main, Europäische Verlagsanstalt, 1969, pp. 343-79.

${ }^{18}$ Caspar Max Brosius, Aus meiner psychiatrischen Wirksamkeit: eine zweite Adresse an die practischen Aerzte, Wiesbaden, 1881, pp. 3, 13.

${ }_{19}$ The scholarly literature on private clinics in Central Europe is meagre. For a brief overview see Erwin $\mathbf{H}$. Ackerknecht, 'Private institutions in the genesis of psychiatry', Bull. Hist. Med., 1986, 60: 386-95.

${ }^{20}$ Svetlin, op. cit., note 14 above, p.113.

${ }^{21}$ See, for example, Heinrich Laehr, Ueber Irrsein und Irrenanstalten, Halle, 1852, pp. 131-2.
} 


\section{A private nervous clinic in late nineteenth-century Vienna}

minds, the entire spectrum of neurological and psychiatric disease. But adding the fudge term "Gemütskrankheit" sent a subtler message to patients and to family doctors. It was, that the clinic accepted lesser mood disorders as well as grave mental and neurological illness, that mild versions of the major mental illnesses (Geisteskrankheiten) would find admission, in addition to the "functional" nervous diseases of hysteria, hypochondria, and neurasthenia. ${ }^{22}$ In contrast to major disorders, these minor nervous and mood complaints were very numerous.

The first clinic exclusively for nervous patients was founded by Otto Müller in 1865 in Blankenburg am Harz in the Duchy of Brunswick. ${ }^{23}$ A wholesale renaming of private insane asylums thereafter would banish the term "insanity" in favor of "nervous disease", or "Gemütskrankheit". "Asylum" itself would give way to "clinic", "treatment centre" ("Heilanstalt"), or simply "Sanatorium". In this manner, a rush of new nervous clinics founded in the 1880s and after (table 2) acquired names with which doctors and patients could feel comfortable.

These private clinics were able to enjoy such huge popularity by side-stepping the stigma of insanity. An anonymous psychiatrist, writing in a professional newsletter in 1902, disapproved of a proposal to rename public insane asylums "Institutes for Nervous Disease", because he could anticipate the reactions of newly-committed patients: "Instead of bringing me to a nervous clinic you've put me in with mental patients!" The author noted that the private clinics had solved this problem with the phrase "Nerven- und Gemütskranke". "'Gemütskrank' is not exactly the right expression", he wrote, "but through the juxtaposition with 'nervous disease' people understand it as they are supposed to. This phrase does not have the offensiveness of 'insane asylum', which is why it has been in use for half a century."24 Thus the concept of Gemütskrankheit neatly blurred the distinction between "mental illness", which one definitely did not want to admit that one's relatives had, and "nervous illness", an organic affection of the nervous system that could happen to anyone and which carried less stigma, thus damaging less the "éclat", or family name. ${ }^{25}$

After the renaming, patients themselves agreed more readily to admission. In former times, to persuade a psychotic relative to accept admission without the asylum's orderlies carting the person away under a court order, the relatives would resort to such stratagems as a proposed trip to a "lovely hotel were shattered nerves

\footnotetext{
22 Both doctors and patients were able to consider the lesser mental disorders as "functional" organic diseases of the nervous system because the whole concept of "psychoneurosis" had not yet gained currency. "Functional" implied, at that time, a disorder organic in nature but without an obvious physical lesion. Although Freud did not coin the term "psychoneurosis", the psychoanalytic movement would popularize it.

${ }^{23}$ See on this Friedrich Albert Erlenmeyer's biography of his father, Adolph Albrecht Erlenmeyer, in Theodor Kirchhoff (ed.), Deutsche Irrenärzte, 2 vols., Berlin, Julius Springer, 1924, vol. 2, p. 45, which mentions that Müller had been an assistant of Erlenmeyer senior in the Erlenmeyer family clinic in Bendorf near Coblenz. Müller then established his own clinic.

24 Anon., 'Ueber die Benennung der Irrenanstalten', Psychiat.-neurol. Wschr., 12 July 1902, 4: p. 181.

${ }^{25}$ Harold Merskey has observed to me in a private communication that, ". . . For many decades the Germans have persisted in maintaining the joint practice of neuropsychiatry when most of the rest of the medical world has split the two disciplines, since it is impossible now for one person to maintain adequate competence in both. The attractions of the combined discipline are of course that the patient can see a neurologist and be treated in fact but not in name as a psychiatric case".
} 


\section{Edward Shorter}

could find rest". Then after arriving at the asylum the relatives would disappear before Auntie Emma realized where she really was. As Ewald Hecker, owner of a private clinic in the Rhineland, explained, such new titles as "Therapy Centre for Nervous Disease" and "Institute for Disorders of Mood and Nerves" were just window-dressing. "Among insiders it is an open secret that these terms have been selected as euphemisms, in order to make it easier for the relatives of a mental patient who might have been horrified at the name insane asylum to bring him in."26

But if such lesser nervous diseases as neurasthenia and hysteria were just organic affections of the nerves, why would a psychiatrist treat them, for psychiatry in those days meant symptoms of mental disorder? This was a potentially awkward question, given that most of the proprietors of the private clinics had been trained as psychiatrists, often doing apprenticeships in public asylums. Why should nervous patients not go to the competing clinics of specialists in internal medicine? The clinic owners' answer was that minor "nervous" disease might lead to more serious psychiatric disorders, that hysteria and psychotic illness were just stages on a continuous spectrum of physical illness of the nervous system. As Heinrich Laehr, one of the leaders in the field of private clinics, put it in 1882, diseases of spirit (Gemütskrankheiten) amounted to "all those pathological conditions which seldom remain without influence on psychic functioning". ${ }^{27}$ Hence, later psychiatric problems might be nipped in the bud through early admission for lesser nervous diseases.

It was, however, two American writers who supplied the most splendid justification of all. Silas Weir Mitchell of Philadelphia and George M. Beard of New York were the true intellectual fathers of the private nervous clinic in Europe. Although Weir Mitchell first described his "rest cure" in 1875, it was not until the 1880s that it became propagated in Germany and France. ${ }^{28}$ The rest cure, with its emphasis upon treating the somatic exhaustion of the patient's "nervous centres" and its efforts to rebuild them through isolation, a milk diet, massage, and electrotherapy, became the procedure of choice in many clinics in Central Europe. Indeed it provided a raison d'être for the clinic, for isolation could not by definition be procured at home, nor could the expensive apparatus of electrotherapy. ${ }^{29}$ Thus various clinics would

\footnotetext{
${ }^{26}$ Ewald Hecker, Ueber das Verhältniss zwischen Nerven- und Geisteskrankheiten, mit besonderer Berücksichtigung auf ihre Behandlung in getrennten Anstalten, Kassel, 1881, p. 13.

${ }^{27}$ Heinrich Laehr, Die Heil- und Pflegeanstalten für Psychisch-Kranke des deutschen Sprachgebietes, Berlin, 1882, pp. iii-iv.

${ }^{28}$ Silas Weir Mitchell, 'Rest in nervous disease: its use and abuse', [April, 1875] in Edward C. Seguin (ed.), A series of American clinical lectures, vol. 1, New York, 1876, pp. 83-102. Mitchell's most influential exposé of his doctrine appeared in Fat and blood and how to make them, Philadelphia, 1877. It was translated in France as, Du traitement méthodique de la neurasthénie, Paris, 1883; in German (from the fourth US edition of 1885) as, Die Behandlung gewisser Formen von Neurasthenie und Hysterie, Berlin, 1887.

29 This account of the transplantation of the rest cure (Mastkur) has been reconstructed from Fernand Levillain, La neurasthénie: maladie de Beard (méthodes de Weir-Mitchell et Playfair, traitement de Vigoroux), Paris, 1891, pp. $237 \mathrm{ff}$; and Valentin Holst, Erfahrungen aus einer vierzigjährigen neurologischen Praxis, Stuttgart, 1903, pp. 18-19. Paul Julius Möbius's Die Nervosität, Leipzig, 1882, provided an initial entry point for Mitchell's ideas, followed by recommendations from, among others, Rudolph Burkart, previously director of the Wasserheilanstalt Marienberg in Boppard am Rhein. See Burkart's 'Zur Behandlung schwerer Formen von Hysterie und Neurasthenie', [Volkmann] Samml. klin. Vortr., [n.d., 1884], no. 245, pp. 1771-1818.
} 
advertise themselves as conducting Mitchell's rest cure, or rather the fattening portion of it, which involved putting the patients on a milk diet. Heinrich Obersteiner's clinic in Vienna kept five cows for this purpose. ${ }^{30}$

Table 2: THE PSYCHIATRIC AND NERVOUS CLINICS IN CENTRAL EUROPE WHICH EXISTED IN 1906: THEIR DATE OF FOUNDATION BY DECADE

Decade in which clinic founded

Before 1849

$1850-59$

$1860-69$

$1870-79$

$1880-89$

$1890-99$

1900-06

No date given
Type of clinic

\begin{tabular}{lc}
\hline Primarily psychiatric & Primarily nervous \\
17 & 2 \\
11 & 1 \\
15 & 1 \\
9 & 3 \\
20 & 8 \\
26 & 11 \\
14 & 10 \\
4 & 17
\end{tabular}

Hans Laehr, Die Anstalten für Psychisch-Kranke in Deutschland, Deutsch-Österreich, der Schweiz und den baltischen Ländern, 6th ed., (Berlin, 1907), passim. The column "mainly psychiatric" includes clinics for "Psychischkranke" and "Gemütskranke". Note that some clinics for "Gemütskranke und leichtere Psychose" had only "open" wards and insisted that the patients be calm. "Wasserheilanstalten" have been excluded. "Primarily nervous" means places advertising themselves for "Nervenkrankheiten" and such.

George Beard's famous "neurasthenia" also appeared in Europe in the early 1880s, promoted by Charcot in France and by the German somatic psychiatrists. ${ }^{31}$ The diagnosis fitted hand-in-glove with the clinics' interests. What could offer a better explanation for the numerous cases of mild depression than "tired nerves"? And the clinic had ways of restoring nerves thought to be physically exhausted. Accordingly, Beard and Mitchell provided the intellectual substructure for the take-off, in the 1880 s, of the private nervous clinic.

The actual distinction between the "nervous" clinic and the "psychiatric" clinic was not that doctors in the former treated nervous disorders expressed in the body, the latter in the mind. It was rather that "nervous" patients admitted themselves

\footnotetext{
30 The Kur- und Wasserheilanstalt (later Kuranstalt für Nerven- und Stoffwechselkranke) in Dietenmühle near Wiesbaden, for example, offered Mitchell's Mastkur. See Paul Berger, Führer durch die Privat-Heilanstalten Deutschlands . . ., Berlin, 1889-90, pp. 45-6. On Obersteiner's cows, see Heinrich Obersteiner, jun., Die Privatheilanstalt zu Ober-Döbling, Wien XIX Bezirk, Hirschengasse 71. Zweiter Bericht . . ., Leipzig, 1891, p. 176.

${ }^{31}$ Although Beard had contributed already in 1869 to the revival of the word "neurasthenia", his influential book on the subject appeared eleven years later. A practical treatise on nervous exhaustion (neurasthenia): its symptoms, nature . . ., New York, 1880. This was translated into German as, Die Nervenschwäche (Neurasthenia). Ihre Symptome, Natur . . nach der zweiten Auflage ins Deutsch übertragen, Leipzig, 1881. This "second edition" of Beard's book also appeared in 1880. Beard's ideas were insinuated into France by French medical authorities, for not until 1895-two years after Charcot's death-did one of his books appear in French. Sexual neurasthenia (nervous exhaustion). Its hygiene, causes . . ., New York, 1884, was translated as La neurasthénie sexuelle; hygiène, causes, Paris, 1895, (based on the third US edition of 1891). On Charcot's godfathering of neurasthenia see, in addition to Levillain, (op. cit., note 29 above), [Joseph-Marie-Alfred] Beni-Barde, La neurasthénie, Paris, 1908, p. 361. Oswald Bumke gave a scathing analysis of the triumphal march in Germany of Beard's neurasthenia in, 'Die Revision der Neurosenfrage', Münchener med. wschr., 23 Oct. 1925, 72: 1815-19.
} 


\section{Edward Shorter}

voluntarily, whereas most categories of psychiatric patients, undergoing psychotic delusions, hallucinations, illusionsand thought disorders, were legallycommitted. Those patients committed by the court suffered by definition from "mental disease" (synonymous with psychosis and thought disorder); those who signed themselves in voluntarily, whose mail could not be restricted, and who could leave at will, had "nervous disease".

Hence nervous clinics were divided into three types: closed, open, and mixed. The traditional private psychiatric hospitals were largely closed, meaning patients could not leave at will. Many of the newer nerve clinics of the 1880 s were "open", having upgraded themselves from water-cure centres. (Closed wards represented larger investments.) But the most prominent of the nervous clinics had both open and closed wards so that all possible patients could be admitted, and patients could be transferred from one to the other, depending on the phase of their illness. Such noted clinics as the "Dr. Erlenmeyersche Anstalt für Gemüts- und Nervenkranke" in Bendorf on the Rhine, or the "Dr. von Ehrenwall'sche Kuranstalt für Gemüths- und Nervenkranke" in Ahrweiler in the Rhineland had both kinds of wards, as did such big Viennese clinics as Heinrich Obersteiner's in Ober-Döbling, later the nineteenth district of Vienna, and Wilhelm Svetlin's in the third district. ${ }^{32}$

This dual arrangement also placated the relatives. As Heinrich Obersteiner, one of the most scientifically respected of the clinic owners, explained, a lot of "nervous" patients were in fact psychiatric cases. "Many patients with lesser forms of psychoses, whose relatives prefer to admit them as nerve patients, are excluded from the [open] nervous division and placed in the [closed] psychiatric division." ${ }^{33}$ Then, as these patients calmed down, they could be removed from the locked wards and permitted to amble about the grounds, socialize freely with other "open" patients, and even take walks in the city. (One of Svetlin's patients escaped during such a walk.) ${ }^{34}$ Many clinical directors had had unpleasant surprises with "nervous" patients who turned out to be psychotic, as for example in cases of early neurosyphilis. ${ }^{35}$ The dual system made it possible to care for them without the disruption and business loss of sending them elsewhere.

But clinics which were completely open also tried to admit psychotic patients, and completely closed clinics might strive to admit nervous patients. Laws stipulating that private insane asylums not admit non-insane patients were widely ignored. In Bavaria a clinic would notify the authorities only if the admission had taken place against the patient's will, regardless of the formal diagnosis or the kind of ward the patient was placed in. ${ }^{36}$ An Austrian decree of 1874 was intended to keep non-psychotic patients out

\footnotetext{
32 See, for example, [Karl von Ehrenwall], Bericht über die Dr V. Ehrenwall'sche Kuranstalt für Gemüthsund Nervenkranke, Cologne, 1898; or the account of the Erlenmeyer clinic in Johannes Bresler (ed.), Deutsche Heil- und Pflegeanstalten für Psychischkranke in Wort und Bild, 2 vols., Halle a/S., 1910-1912, vol. 1 , pp. 521-36.

33 Obersteiner, op. cit., note 30 above, p. 41.

34 Svetlin case no. 301, Marie von M. A Catholic woman from Lemberg and landowner's daughter, she had been engaged to an army officer, who helped commit her to Svetlin's clinic for "insanity" [irr. Wahnsinn]. On the day before Christmas 1888, she escaped during a walk in Vienna's Kärtnerstrasse, and five days later was hospitalized again in the Schwartzer private clinic in Budapest.

35 Ehrenwall, op. cit., note 32 above, p. 61.

36 See Ernst Rehm, 'Kuranstalt Neufriedenheim bei München', in Bresler, op. cit., note 32 above, vol. 2, p. 398. Legally, however, within the German Empire only in Prussia could a private insane asylum have an
} 


\section{A private nervous clinic in late nineteenth-century Vienna}

of "insane asylums". But the psychiatrist Julius Wagner von Jauregg pointed out that "closed" clinics had long been admitting alcoholics, morphine addicts, and obsessivecompulsives, patients who were mentally ill in clinical terms although not confined legally. He also wrote that "open" clinics had long made a practice of taking on psychiatric patients, whose families would send them there precisely because they wanted to avoid the stigma of an "insane asylum". 37

Yet even though "open" clinics did admit psychiatric patients, they advertised that they did not. Their ads would stipulate that psychotics and epileptics were excluded, thus strengthening their appeal in the minds of the relatives while filling their empty beds. (The risk was that these unwatched patients might commit suicide.) ${ }^{38}$ Thus, rather than there being two separate kinds of clinics, psychiatric and neurological, in practice there was only one: the nervous clinic.

What did these clinics have to offer therapeutically? In the days of "therapeutic nihilism," a dubiety about therapy which concerned pre-eminently drugs, doctors had at their disposal basically diet and the physical therapies: long water baths, massage, and electricity. Restraint was frowned upon. In keeping with the general acceptance of the "open door system", borrowed from the British, clinics congratulated themselves on turning their isolation cells into day rooms and the like. The closed wards did restrain psychotic patients, but the clinic physicians tried to do it in ways that would horrify the relatives least, such as using beds it was impossible to climb out of.

Clinic directors also had a definite concept of "psychotherapy", the basis of it being, in Obersteiner's words, "the two ancient techniques with which the little griefs of children have always been treated: pacifying and distracting them". They pacified patients by calming their fears in close conversation (for the ratio of doctors to patients in these expensive clinics was quite favourable), by curtailing family visits, and by such external agencies as long baths. Obersteiner believed these techniques actually reduced irritation (Hirnreiz) in brains that had been physically overstimulated. ${ }^{39}$ As for distraction, the clinics offered the therapy of persuasion, talking patients out of their pathological ideas. Although occupational therapies were available, they had little appeal for an upper-class clientele accustomed to the notion that only servants did garden and handwork. The main distractions were endless theatre visits, concerts, outings, and parties organized by volunteer "hostesses" ("Gesellschafterinnen") from the town's upper crust. In private clinics the patients would often take their meals with the doctor's family. In many ways, then, the troubled mind would be calmed, the "agitated" nervous system soothed. ${ }^{40}$

A flood of new hypnotics (drugs for insomnia) and sedatives in the 1860 s and after marked the rejection of therapeutic nihilism in nervous disease. Morphine was

open ward. See Ernst Beyer, 'Nervenheilstätte, Sanatorium und Irrenanstalt', Psychiat.-neurol. Wschr., 18 Sept. 1909, 11: 229-32.

${ }_{37}$ Julius Wagner von Jauregg, 'Unterbringung von Geisteskranken in Privatheilanstalten', Öst. SanitätsWesen, 1905, 17, copy of offprint in library of Institut für Geschichte der Medizin in Vienna, pp. 1-2.

${ }^{38}$ See on this Caspar Max Brosius's essay in Irrenfreund, 1882, 24: 3-4; Valentin Holst, Ueber die Bedeutung der Behandlung von Nervenkranken in besonderen Anstalten, Riga, 1880, pp. 3-7.

${ }^{39}$ Obersteiner, op. cit., note 30 above, pp. 144-6. Obersteiner's clinic also tried hypnosis, a technique against which psychotic patients were refractory, but to which neurotic patients responded well.

40 The sections on the private clinics in Bresler, op. cit., note 32 above, offer an overview of these issues. 


\section{Edward Shorter}

introduced into German psychiatry in 1863 , chloral hydrate in 1869 . Other such products of Germany's blossoming organic chemical industry as sulfonal and paraldehyde made it possible almost definitively to abandon the restraint of private patients. ${ }^{41}$

But in addition to the drugs that did work, clinic doctors also gave numerous drugs that did not work, which is to say, that have not stood the test of time in dealing with agitated psychoses. Thus Freud's patient Mathilde S., once delivered into the Svetlin clinic, received for her mania, in addition to chloral hydrate, "hyoscin", (or hyoscyamine, from the seeds of henbane), digitalis and ergot, cannabis, and "lupulin" (the bitter aromatic principle contained in hops). "Three days later [after an initial outbreak of acute delirium] she begins hallucinating animals, just at the onset of her period. Now the maniacal delirium concerns almost exclusively sexual matters: she thinks herself pregnant, every bowel movement is a birth, the faeces are her baby, the 'jewel of her crown' which she seeks to conceal from the orderly under a pillow." They gave her digitalis and she was, perhaps coincidentally or via suggestion, calmed. Two months after admission, her delirium had subsided but she then believed herself to be Joan of Arc, and wore her bedpan on her head as a helmet. They gave her cannabis .... On and on it went for seven months. ${ }^{42}$ The private nervous clinic thus had a wide variety of drugs of varying effectiveness at its disposal.

\section{NERVOUS CLINICS AND NERVOUS PATIENTS IN VIENNA}

Vienna, the world capital of hysteria as some imagine it, was not underserved by private nervous clinics (see table 3). But they did not treat hysteria. We first set the stage, then see what they did treat.

The oldest and socially perhaps most distinguished of Vienna's private psychiatric clinics was founded in 1819 by Dr Bruno Görgen in the village of Gumpendorf, which lay just outside the inner city to the west. In 1831 Görgen moved the clinic to newly built quarters in the lovely village of Ober-Döbling to the north, almost in the shadow of the Kahlenberg heights. The beauty of the setting was deemed clinically important, dosing the patients as it did with tranquillity and by encouraging long walks in the clinic's extensive grounds. Görgen himself died in 1842, but his son Gustav took over the management of the clinic until 1860. In that year one of the patients, the Hungarian politician Count Stephan Szechenyi, committed suicide after the police had searched his room for subversive material. Görgen was so heavily criticized for letting Szechenyi obtain a pistol that he decided to get rid of the clinic, leasing it later in 1860 to Max Leidesdorf and Heinrich Obersteiner, senior. When Obersteiner senior died twelve years later in 1872 , his son, Heinrich Obersteiner, junior, a recent medical graduate, took over with Leidesdorf the co-administration of the clinic.

\footnotetext{
${ }^{41}$ Grunau, op. cit., note 3 above, p. 34. The hypnotic paraldehyde was discovered in 1883, sulfonal in 1887.

${ }^{42}$ Svetlin, op. cit., note 1 above, p. 143. Given that headache, fatigue, malaise, and drowsiness are common effects of digitalis intoxication, the drug has lent itself in the past to psychiatric use. It may, in fact, calm mania at dangerously high doses, but may also induce delirium and hallucinations. See Alfred Goodman Gilman, et al. (eds.), Goodman and Gilman's The pharmacological basis of therapeutics, 7th ed., New York, Macmillan, 1985, p. 740, on neurological effects of digitalis intoxication.
} 


\section{A private nervous clinic in late nineteenth-century Vienna}

Table 3: PRIVATE NER VOUS CLINICS IN VIENNA

Location

1 Ober-Döbling, Vienna XIX

2 Svetlin clinic, Vienna III

3 Lainz, Vienna XIII

4 Inzersdorf, Vienna XXIII

5 Tulln, nr. Vienna

6 Hacking, Vienna XIII (now XIV)

7 Pressbaum, nr. Vienna (after 1913 in Rekawinkel)

8 The Sanatorium of the

"Steinhof", Vienna XIV
Date of founding

1819

1834

$1863 / 1872$

1872

1884

1888

1906

1907
Most prominent physician

Heinrich Obersteiner/

Max Leidesdorf

Wilhelm Svetlin

Moritz Löwinger

Moritz Pokorny

Emil Fries

Giuglio Bonvicini

Moritz Rosenthal

Siegmund Weiss

various directors

In addition to the special reports about the Svetlin and Obersteiner clinics, cited in the notes, see the annual volumes of the Niederösterreichisher Amts-Kalender, which lists all medical institutions in public and private sectors. The "Lainz" clinic was founded in 1863 , then in 1872 incorporated the patients of a clinic which Dr J. Treue had founded in 1860 in Vienna's third district. The Sanatorium in Tulln was first founded in 1884 for retarded children, began in 1895 taking demented adults as well, and only in 1913 officially became a "Sanatorium". Although the Steinhof psychiatric hospital was a public institution, its Sanatorium was designed for well-paying private patients and was intended to make a profit. It is thus included here, while the two charitable neurological hospitals of the Rothschild Foundation are excluded. All the nervous clinics in this table had both open and closed wards with the exception of the Sanatorium in Hacking, which excluded (it said) "Geisteskranke und Epileptische". In 1896 it began admitting sufficient numbers of non-nervous patients that the government no longer considered it a "psychiatric" institution. The clinics in Pressbaum and Hacking are not mentioned in Laehr's guides cited elsewhere in this article.

Obersteiner junior married Leidesdorf's daughter, and after Leidesdorf's death in 1889, became the sole operator of the Ober-Döbling clinic. Here he stayed until 1916, retiring at the age of sixty-nine and selling the clinic's grounds to a real estate company. ${ }^{43}$ Sigmund Freud, who worked at the clinic in 1885 , gives us a picture of a quiet, cool place where "one really could lead an idyllic life". ${ }^{44}$

These clinics were basically family affairs. Obersteiner's marriage to Leidesdorf's daughter consolidated the ownership. In many clinics the property would pass from generation to generation: the Rockwinkel clinic in Bremen, in the hands of the Engelken family for at least five generations, was the longest-standing example of this. $^{45}$

Yet even though in place by family compact, the operators of the clinics often had considerable scientific attainments. Leidesdorf occupied one of the two Viennese

\footnotetext{
43 Sources for this account include Joseph Johann Knolz, Darstellung der Humanitäts- und Heilanstalten im Erzherzogthume Oesterreich, Vienna, 1840, pp. 296-302; Franz Englisch, 'Die Döblinger Privatirrenanstalt: ein Beitrag zur Geschichte der Wiener Pflegeanstalten für Geisteskranke', Wiener Geschichtsbl., 1969, 24: 398-405; Obersteiner, op. cit., note 30 above, pp. 2-3; accounts of the lives of Leidesdorf and Heinrich Obersteiner jun. may be found in Kirchhoff, op. cit., note 23 above, vol. 2, pp. 15-18, and vol. 1, pp. 103-5. On Obersteiner see also the dossier in the "Biographische Sammlung" of the Wiener Stadt- und Landesarchiv.

${ }^{44}$ Ernst L. Freud, Letters of Sigmund Freud, New York, Basic Books, 1960, letter no. 68 to Martha Bernays, 8 June 1885 , pp. 150ff. The editors mistranscribed Freud's references to the co-director Max Leidesdorf ("an old gentleman, converted Jew, twisted features") as "Prof. B.", not "L."

${ }^{45}$ On Rockwinkel bei Bremen see Laehr, op. cit., table 2 above, pp. $28-9$.
} 
chairs of psychiatry from 1875 to 1889 . Obersteiner junior founded, in 1882 , the university's neurological institute, paying for it from the personal fortune which clinic ownership had conferred upon him. He went on to make important contributions to the anatomy and pathology of the nervous system. He has, indeed, an eponym: the "Obersteiner-[Emil] Redlich area", the point where the posterior nerve roots enter the spinal cord. ${ }^{46}$ Thus Freud's fear, expressed to his fiancée Martha in that summer of 1885 , of falling to sleep scientifically at the Obersteiner clinic, might not have been entirely justified.

By contrast, Wilhelm Svetlin, owner of Vienna's second oldest and perhaps second most reputable nervous clinic, was not a scientifically distinguished man. Locally he was immensely respected, and by 1910 had been both president of the Austrian Medical Society and of the Viennese Doctors' Collegium (Doktoren-Kollegium). But as a believer in old-fashioned "reflex" theories about the causes of mental illness-for example that masturbation causes madness-he got nowhere scientifically among the "brain-disease" crowd that dominated Viennese psychiatry. Like Obersteiner he was Catholic but, unlike Obersteiner, Svetlin was of humble origin: his father had been the great Joseph Hyrtl's laboratory assistant. Born in 1849, Svetlin got his medical degree from Vienna in 1873, and spent several years working with Leidesdorf, both at the university psychiatric clinic and at Leidesdorf's Ober-Döbling private clinic. In 1878, together with a partner, Svetlin bought a clinic of his own. ${ }^{47}$

The history of the clinic that he bought began in 1829, when Regimentsarzt Dr Pabst transferred from Melk (Mölk), which is nearby on the Danube, to Vienna. To help make ends meet in Melk, his wife Theresia had taken in the occasional mental patient as a boarder. She continued to do this after arriving in Vienna, just as several other genteel Viennese ladies ran quiet boarding houses, tolerated but not officially licensed, for mental patients. After Dr Pabst died in the cholera epidemic of 1832, Theresia began to expand her operations, and in 1834 received a licence from the government to care for "peaceful insane patients [Irre] and the mentally ill" in the ten-room house she had leased. She recruited a medical director in 1840, moved eight years later to the roomier quarters of a former summer palace of Prince Rasumofsky, in what would later be the third district, and by then had individual rooms for twenty-three patients. Thus the industrious Frau Pabst built the care of psychiatric patients into a thriving business. But as she aged she neglected the business somewhat, and ended up at the time of her death in 1878 with just a handful of chronic female patients. At this point Wilhelm Svetlin got together with her physician, Johann Zimmermann, and bought the clinic from her heirs.

But as Svetlin and Zimmermann received their concession from the government in 1879, the partners insisted that it be for a treatment clinic (Heilanstalt) and not just for the chronic-care centre (Pflegeanstalt) that Frau Pabst had been running. They

\footnotetext{
${ }^{46}$ On Obersteiner jun., see Erwin Stransky's biographical note in Grosse Österreicher, Zurich, Amalthea-Verlag, 1957, vol. 11, pp. 173-6.

${ }^{47}$ Information about Svetlin's life comes from the archive of the Universität Wien, "Haupt Rigorosen Protokoll, 1872-94”; from Ludwig Eisenberg, Das geistige Wien, Vienna, 1893, vol. 2, p. 484; and from newspaper accounts of his death, Neues Wiener Tagblatt, 25 Aug. 1914, p. 11, and Neue Freie Presse, 25 Aug. 1914, p. 9. As an instance of Svetlin's ideas, see his misogynistic pamphlet, Die Frauenfrage und der ärztliche Beruf, Vienna, 1895.
} 
could thus move into the active treatment of psychiatric and nervous patients (for psychiatric clinics licensed before 1874 in Austria were permitted to take on non-psychiatric cases as well). ${ }^{48}$

When Svetlin bought the clinic he had space for thirty patients in twenty-two rooms, but only limited grounds, and little space for baths, physical therapy, and so forth. In 1884, therefore, he built new quarters with spacious gardens further south in the third district, and added to this building over the years. By the time he sold the clinic in 1902, his health evidently failing, the clinic could accommodate seventy patients. ${ }^{49}$

What kind of patients came to Svetlin's clinic? Wealthy, above all. At two hundred guilders a month, the clinic was aimed at the upper crust of Austro-Hungarian society. ${ }^{50}$ Although the Ober-Döbling clinic was said to be even more exclusive, the roster of Svetlin's patients is impressive enough. In 1887 Prince X, seventeen, was admitted for what sounds like schizophrenia. ${ }^{51}$ Baron I., aged sixty, came in for symptoms that may have corresponded to Alzheimer's disease. ${ }^{52}$ The young Baron von P., at thirteen probably the clinic's youngest patient, had some disorder that caused his transfer to the provincial insane asylum at Ybbs; his brother (or uncle), an army officer, ended up in the clinic with progressive paralysis. Baron U., twenty-six, and Count de M., twenty-five, were both treated for a morphine addiction. And in 1891 Count R. was admitted for "paranoia". ${ }^{53}$ Thus patients at the clinic would rub shoulders with the high nobility of the Austro-Hungarian Empire.

An occupational analysis is not terribly interesting because it merely catalogues the social groups able to pay the fees. In Wilhelm Svetlin's own analysis of the 300 patients discharged from the clinic between circa 1885 and 1890 , he identified 27 per cent as "private", meaning independently wealthy, 16 per cent as "aristocrats, rentiers, and landowners", 15 per cent as merchants, 8 per cent as industrialists, and so forth, across an occupational scale that includes doctors, officials, lawyers, clerics, and army officers, but has no artisans, handworkers, or peasants, and only the few servants, gardeners, and music teachers whose wealthy masters were willing to pay the bill. ${ }^{54}$

48 The early days of the clinic are recounted in Svetlin, op. cit., note 14 above, pp. 3-9. Zimmermann retired from the operation of the clinic in 1880 . See also Knolz, op. cit., note 43 above, where the "Verpflegs-Anstalt der Madame Pabst, Med. Doktorswitwe für stille Geisteskranke und andere chronische Leidende" is discussed pp. 303-4.

${ }^{49}$ These details from Svetlin, op. cit., note 14 above, and from annual volumes of the NiederÖsterreichischer Amts-Kalender.

${ }^{50}$ In a letter of 18 August 1892 , Svetlin thanked an unnamed addressee for her payment of 200 guilders for a month's care of her mother. The mother was Frau v. H., who in 1890, at age 77, had been admitted to the clinic (case no. 422). She died there eight years later. Letter in Handschriftenabteilung of the Wiener Stadtund Landesbibliothek, H.I.N. no. 10889. To assess how much $200 \mathrm{fl}$. a month was, keep in mind that one of Arthur Schnitzler's girlfriends, Jeanette, earned $20 \mathrm{fl}$. a month as a seamstress in the late $1880 \mathrm{~s}$ in a loft (Sticksalon), working daily from eight until one, and three until seven. Schnitzler, Jugend in Wien, Vienna, Fritz Molden, 1968; pb. ed. Fischer Taschenbuch), p. 301.

51 Svetlin case no. 226. Kaan gave the case history in Svetlin, op. cit., note 1 above, p. 131.

52 Ibid., case no. 366. Details from Kaan in Svetlin, ibid., p. 112.

53 These are case nos. $426,223,253,111$, and 453.

54 Ibid., p. 25. Heinrich Obersteiner undertook a similar occupational analysis of 767 of his recent patients, subdividing them by male and female, and psychiatric versus nervous. Thirteen per cent of the total were "Nervenkranke". Op. cit., note 30 above, p. 68. 


\section{Edward Shorter}

In geographical terms the clinic, like the empire as a whole, was turned to the east. Because we shall later distinguish clinically between Jews and non-Jews, we analyse them separately, discussing the non-Jewish patients here. Of the 320 non-Jewish patients seen between 1879 and 1891 , only 28 per cent had their legal residence (Zuständigkeitsort) in Vienna. The permanent residence of a further 13 per cent was elsewhere in Austria, 13 per cent in Hungary, 9 per cent in Bohemia, 6 per cent in Moravia, and 6 per cent in Galicia. Only a further 6 per cent came from Germany. The remaining 20 per cent stemmed from elsewhere, overwhelmingly from such places as Rumania, Russia, Dalmatia, Bulgaria, and Croatia. The non-Jewish clientele of the clinic came, in short, from the landholding nobility and small-town merchant class of Eastern Europe.

DIAGNOSES: DISEASES OF THE SUBSTANCE OF THE BRAIN

What afflictions did these clinic patients have? As table 4 shows, they were not trivial complaints, not society gentlemen feeling a bit "liverish", nor society ladies with a touch of the "vapours". Such patients let themselves be treated at water-cure centres and spas.

Table 4: RETROSPECTIVE DIAGNOSES OF PATIENTS IN THE SVETLIN CLINIC, 1879-91

$\begin{array}{lcc}\text { Diagnosis } & \text { No. of patients } & \text { Percentage } \\ \text { Organic brain syndrome } & 28 & 6 \\ \text { Neurosyphilis } & 87 & 19 \\ \text { Alcoholism } & 9 & 2 \\ \text { Morphinism } & 34 & 7 \\ \text { Mania } & 38 & 8 \\ \text { Major depression } & 88 & 19 \\ \text { Possible schizophrenia } & 85 & 18 \\ \text { "Hysteria" } & 9 & 2 \\ \text { Other (or diagnosis absent) } & 90 & 19 \\ \text { Total } & 468 & 100\end{array}$

Organic brain syndrome. Clinic staff would invariably give psychiatric diagnoses, yet a number of patients obviously had an underlying disease of the nervous system, which the doctors noted coincidentally or which became apparent in retrospect because they died soon after admission. Thus Heinrich M., a married army officer and landowner from Styria, checked into the clinic in September 1888 with a "mental disturbance and paralysis". He had previously sought help at a sanatorium on the Ausseer See, a lovely lake, but became too ill for its staff to manage. The sanatorium director sent him on to Svetlin, with a request by the patient's brother, also an army officer, for admission. The staff later made the diagnosis "tumor in cerebro", and the man was discharged eight months later somewhat improved. ${ }^{55}$ Therese F., thirtythree, a divorced Catholic from small-town Austria, was diagnosed on admission, in June 1881 , as having a psychosis ("Verrücktheit"). The police commissioner of her little town had accompanied her to Vienna. She died three months later. ${ }^{56}$ Evidently

${ }^{55}$ Svetlin case no. 296.

56 Svetlin case no. 51: "verh. (geschieden)" was written under "Stand". 
her psychosis was caused by some intercurrent organic disease, which may well also have caused her divorce. The clinical staff employed the new neurological tests known to them, such as the patellar reflex ("knee-jerk") and the "Romberg sign" (loss of balance with eyes closed and feet together, a sign of tabes dorsalis and other diseases that harm the sensory tracts of the spine and cerebellum). Yet the fact that they missed so many organic diagnoses indicates how primitive the level of clinical neurology was before the turn of the century.

Neurosyphilis. As we have seen, the diagnostic categories of the time were "tabes dorsalis", "progressive paralysis", and "dementia paralytica", only rarely "syphilis". Only after 1913 would it be decisively demonstrated that a bacterial micro-organism caused all of these diseases which previously had been considered as separate entities. 57 The point is, however, that the Svetlin doctors' diagnoses of "tabes" and "progressive paralysis" may be considered accurate. Their failure to realize that they were dealing with syphilis of the central nervous system does not prevent us from establishing that their patients in fact suffered from neurosyphilis.

One out of five clinic patients had syphilis of the central nervous system. And this already impressive statistic underestimates the true magnitude of the disease, for not a single female patient was diagnosed with neurosyphilis. Indeed, the diagnosis was suspected in one woman, the wife of a wealthy butcher in Baden bei Wien who arrived in a state of high sexual excitability, but after a second admission they settled on "acute delirium". 58 In the Svetlin clinic, neurosyphilis was deemed a disease of males only: of 264 male patients admitted between 1879 and 1891, 33 per cent had it.

The finding of neurosyphilis exclusively in males was not owing to some clinical blindspot of the staff. In public asylums, a fair percentage of female admissions had dementia paralytica or progressive paralysis, but in middle-class settings it was extremely uncommon for wives to be infected, because the infectious stage of the disease is limited to a year or two. Typically, the husbands would acquire it from prostitutes before marriage, and the contagious, open mucocutaneous lesions would have vanished by the time they married. ${ }^{59}$ In 1849 , the English psychiatrist John Conolly said that in private practice he had never seen a case of dementia paralytica in a woman. ${ }^{60}$ In his private Ober-Döbling clinic, Heinrich Obersteiner had only encountered three cases in women, in contrast to 182 in males. ${ }^{61}$ In Frau Pabst's clinic from 1834 to 1884 , a period in which many more women than men were admitted,

${ }^{57} \mathrm{H}$. Noguchi and J. W. Moore, 'A demonstration of Treponema pallidum in the brain in cases of general paralysis', J.exp. Med., 1913, 17: 232-8. The saga of neurosyphilis after $c$. 1850 has yet to find its historian.

58 Anna F.'s first admission, no. 420, occurred on 11 Dec. 1890; her second, no. 461, on 9 May 1891. Details from Kaan, in Svetlin, op. cit., note 1 above, pp. 124-5. "Dement. paral.?" was written as her first diagnosis, then replaced by "sekundäre Geistesstörung".

59 A classic account of these good family fathers with neurosyphilis is Léon Daudet's Devant la douleur: souvenirs des milieux littéraires, politiques, artistiques et médicaux de 1880 à 1905, Paris, 1915, pp. 237-58, where the author describes the stays of his stricken father, Alphonse Daudet, at the French spa Lamalou. Middle-class, middle-aged Viennese men were constantly at risk of contracting the infection. For example, in Robert Musil's novel Der Mann ohne Eigenschaften (1930), "Sektionschef Tuzzi" continued into marriage his habit of regularly visiting a bordello, (new ed., Reinbek bei Hamberg, Rowohlt, 1978), vol. 1, p. 105.

${ }^{60}$ Quoted in Hare, op. cit., note 7 above, p. 617.

${ }^{61}$ Obersteiner, op. cit., note 30 above, p. 49. 


\section{Edward Shorter}

neurosyphilis was seen only in nine women, fifty-eight men. ${ }^{62}$ Among the middle- and upper classes, therefore neurosyphilis was in fact a male disease, and the main reason for admission to a nervous clinic.

Moreover, it struck in the prime of life, unlike stroke or Alzheimer's disease. The average age of male patients with neurosyphilis on first admission to the clinc was 43.4. In the Ober-Döbling clinic, the great majority of paralysed psychotic patients (most of whom had diagnoses of progressive paralysis or had previous histories of "lues") were middle-aged men. ${ }^{63}$

The proportion of one in three is probably an underestimate for men, because the early symptoms of the disease were difficult to differentiate from "hysteria" and "neurasthenia", involving as they did subtle personality changes, a sudden indifference to grooming, and undeliberated purchases of wagon-loads of wine and expensive oil-paintings. Brosius mocked the families for their reluctance to consider that the beloved family father might need institutionalization. "Could we send this man . . . could you send such a patient to an asylum?! He's still much too rational for that! He still speaks very distinctly! And he was always excitable!"64

In the long list of army officers, merchants, and privately-wealthy noblemen admitted to the clinic with progressive paralysis, Sir Ludwig von $\mathrm{Z}$. (the Ritter von Z.), thirty-eight, is typical. He came in on New Year's Day 1888, his wife and father having requested his admission. What did he seem to have? "Acute neurasthenia", but the court had approved his committal, so already he was demonstrating psychotic symptoms, one of which might typically have been running through the family fortune, a sign among this social class of psychotic behaviour. At age twenty-three he had had an ulcer on his groin and underwent a mercury cure. Then nothing untoward occurred until, at thirty-four, he noted leukoplakia (white, thickened patches) on his mouth and tongue, possibly a brief manifestation of the secondary spread of his syphilis. Six months after that he fainted for half an hour, and was paralysed on his left side with difficulty in speaking. (Note how widely the diagnosis of "neurasthenia" could extend.)

But once in clinic his symptoms worsened, his left side dragging, with loss of vision in his right temporal field. Dramatic personality changes occurred as well. He began having premonitions of death: "The coming year will bring something terrible, [I] will certainly become insane." Three months later he was discharged, threatened suicide at home, and in April of 1889 was readmitted. He evinced more of the same kinds of symptoms, and we lose sight of him once he was discharged a second time on 15 June. ${ }^{65}$

Unlike the Ritter von Z.'s neurosyphilis, which took its time to run downhill, more than half of the 87 neurosyphilis patients admitted to the clinic died there. Many others were transferred to public asylums such as the Lower Austrian Insane Asylum

${ }^{62}$ Svetlin, op. cit., note 14 above, p. 67.

${ }^{63}$ Obersteiner, op. cit., note 30 above, p. 65. In "Geistesstörung mit Lähmung", the modal group is 35-40, with 48 male patients out of a total 190 males having that diagnosis. There were no females in that age group.

${ }_{64}^{64}$ Brosius, op. cit., note 18 above, p. 24.

${ }^{65}$ Svetlin case nos. 254 and 332. At the time of the patient's first admission, another hand had written "Prog. Paral." next to "Neurasthenia acuta". And the diagnosis at his second admission was "Melancholie 


\section{A private nervous clinic in late nineteenth-century Vienna}

(Niederösterreichische Landes-Irrenanstalt). Once they had become demented and beyond hope of recovery, the relatives saw no point in spending further money on them. If a single spectre haunted men, then, in the world of nervous disease, it was dementia and death from "progressive paralysis".

Alcoholism. The nine patients admitted with alcoholic psychosis or delirium tremens were all males. All save one (a 59-year-old factory owner) were in their thirties and early forties. Two were Jewish. Three were exposed to alcohol as an occupational risk: a Jewish wine merchant from a small town in Hungary, and two innkeepers from Simmering, a southern suburb of Vienna. ${ }^{66}$ All were discharged "healed" except for one patient who was healed the first time and then after a second stay lasting seven months was sent to the provincial insane asylum. Alcoholism in those days, like neurosyphilis, was almost entirely a male disorder.

Morphinism. Morphine, the other great drug of abuse in the late nineteenth century, was not at all a monopoly of men. And with 34 cases in the clinic, amounting to 7 per cent of all admissions, morphine addiction was considerably more common among the middle- and upper classes than alcoholic psychosis. Indeed, a number of private nervous clinics advertised themselves as specializing in morphine withdrawal. ${ }^{67}$ While Svetlin did not specifically mention withdrawal therapy in his own advertisements, many of these morphinists nonetheless came from far away to seek help. (By contrast only 3 per cent of Heinrich Obersteiner's patients in the years 1875-91 were morphine addicts. $)^{68}$

Among the morphinists were seven women and twenty-seven men, the women aged 32 on average, the men 34 and a half at the time of their first admission. Of the seven women, three were doctors' wives; of the twenty-seven men, eleven were doctors. ${ }^{69}$ It is of some interest that two of the males counted here as "morphine" addicts were in fact addicted to cocaine, a pest which Freud himself helped unleash upon the world in 1884 . Thus Dr Leopold M., thirty-four, a regimental physician stationed in a small town in Moravia, and Carl von L., thirty, a lieutenant in the Hussars stationed somewhere in Hungary, must have been among Austria's first cocaine addicts. ${ }^{70}$

So much for the organic mental disorders, the external chemicals and microorganisms that affect the mind by acting on the brain. How about the mainline psychoses?

\section{DIAGNOSES: MANIA AND DEPRESSION}

Mania. Countess X, a member of the high Hungarian nobility, was a typical mania patient. We review her case not merely to illustrate mania but to convey a sense of real life in a clinic. She was twenty-four when the last-born and best-loved of her three children

\footnotetext{
(Prog. Paral.)". Surprisingly, Kaan insisted on referring to the case as "Pseudoparalyse", in Svetlin, op. cit., note 1 above, pp. 110-11.

${ }^{66}$ The Jews were Sigmund R., no. 43, and Sigmund S., no. 279; the Simmering innkeepers were Michael F., no. 28 , and Elias S., no. 391.

${ }^{67}$ See, for example, "Dr. Emmerich's Heilanstalt für Nerven-, Morphium- und dergl. Kranke in Baden-Baden", which promised in 5-7 weeks "a certain and above all lasting cure without compulsion or misery [Qualen]", in Paul Berger, Führer durch die Privat-Heilanstalten Deutschlands, 6th ed., Berlin, $1898-99$, pp. 83-6.

68 Obersteiner, op. cit., note 30 above, p. 45 .

${ }^{69}$ Obersteiner found that, of his 21 morphine addicts, 11 were doctors and one a doctor's wife. Ibid, p. 120.

${ }^{70}$ Both were admitted in 1891 . Svetlin case nos. 432 and 503 .
} 
died of diphtheria. "Since then her equilibrium has been shaken ... . She kissed the beloved child so long that she herself got an infection, and stood for hours at its grave until she saw it in the clouds! Since the day of the child's death, her nervosity has increased steadily. The patient spends hours in the church, even in the bitterest cold."

During the summer of 1896 the agitated, grieving mother moved from estate to estate among her family's possessions in Hungary, in August passing through a village in which a typhoid epidemic was raging. In October she came down with a fever and diarrhoea, and simultaneously became delirious, screaming, hallucinating, and moving her hands continuously. The hallucinations acquired sexual content. She lost control of her bowels. "On the 5th of November the patient expresses the belief that she has been dead until the present and is now resurrected. On the 7th of November, depressed mood, she believes she has deceived her husband and has maniacal excitement. November 8 to 12 , isolated hallucinations and deranged ideas to the effect that her mother-in-law is persecuting her. Patient becomes aggressive, destructive, demands that her husband take a whip to everyone around her."

Over the next few days, still in Hungary, the young Countess $X$ tipped into a full-blown mania, "speaks day and night, sings and whistles, acquires the delusion that her attendants want to teach her how to do an abortion, should the need ever arise."

November 18-19: "Thoughts tumble forth, rhymes and song. Is very aggressive. Since the 17th, profuse menses. She brings the business about the completed miscarriage into connection with a certain Count X."

Five days later, her increasing agitation had made further home care impossible and on November 24 she was admitted to the Svetlin clinic in Vienna, in the grips of mania.

On admission, she did not know where she was, nor what day it was. "Speaks loudly and confusedly, curses those around her yet clings to her attendant". The following day they did a physical examination, discovering little except a left-sided "ovarie", a concept Jean-Martin Charcot had popularized in which pressure on one of the lower quadrants of the abdomen - thus on the "ovary"-is supposed to unleash a hysterical response.

"The patient soon recognizes the doctors as such, but quickly becomes irritated and begins to scold them. On the motor side she is very restless, makes quick little movements, expresses the belief that she is an 'ape', soon calls everyone else 'apes', identifying them as gorilla, chimpanzee and so forth. Then she leaps from bed onto the table, wraps the covers about her in different ways, amidst much uproar identifies herself as two different apes, and wants to go to [the zoo at] Schönbrunn, and everybody else should come along." (She had brought with her an entourage from Hungary, in addition to the clinic's own orderlies assigned to her.)

November 27: "She says she thinks she is in a whore-house [Haus von Cocotten], has to do abortions and so forth. Curses."

There followed a long period of throwing her food on the floor, endless masquerades with the covers, taking off all her clothes, and making little forts of clothing in her barred bed. She was still hallucinating and "identifies her doctors as people from her personal circle, calling them 'Absalom', 'Rothschild' and the like".

On 16 January 1897, for example, "she is restless, constantly changing her clothing style around, getting up and lying down in one place then another, switches the 
furniture around, occasionally becomes somewhat aggressive. Because of the danger that she will demolish things she must again be confined to bed."

On 25 March she believed that she was in Otto Schwartzer von Babarcz's nervous clinic in Budapest. She thought that everyone had been giving her injections and hypnotizing her, that "her child has been stolen away from her in a tetanus attack, that it is still alive, that she still sees it over there and that it too has recognized its mother despite the distance. That she is still in the clinic is a plot of the relatives, that her husband is much too effeminate and too weak in order to put an end to the relatives' schemes, that the only one who is able to get anything done is her father."

A month later she was calmer, was shifted into the open ward, and started demanding to be released. By 27 April she was eating with the other patients at the common table. On 2 May she received her first visitor, and all passed quite normally. A week later she made her first excursion into the city, and on 17 May she was "discharged well".71 This, then, was mania.

Between 1879 and 1891 thirty-eight patients were admitted for mania. Their average age was 30 . The Countess $X$ was untypical of most mania cases in that she was treated at home for several months before her admission. But then her family had ample servants and doctors at their beck and call. Most families could not cope with even a short episode of mania, and in contrast to neurosyphilis or depression, where the patient might have been in family care for years before being hospitalized, two-thirds of Svetlin's mania cases had been symptomatic less than a month before the family sought admission. ${ }^{72}$

Manic-depressive disease, or "bipolar disorder". 73 Mania usually occurred in connection with depression, and the diagnosis "manic-depressive illness" was recognized in Svetlin's day in such phrases as "circular insanity". ${ }^{74}$ According to Karl Friedrich Flemming, one of the fathers of German psychiatric diagnosis, depression alternated with mania in one case of major depression in five. ${ }^{75}$ Thus, even though mania was given a separate diagnosis in the clinic, it is probable that many of these patients were, in fact, manic-depressives. Just how many is unknown because the admission register contains no history, only a diagnosis of one word. The number

\footnotetext{
${ }^{71}$ Dossier in the archive of the Psychiatrisches Krankenhaus der Stadt Wien. The existence of her entourage is known from a note that her mother, a member of another illustrious Hungarian noble family, penned on a visiting card to Svetlin from a hotel in Vienna, shortly before her daughter's admission. In the file is a pencilled plea for help, which the Countess, in the belief that she was in a Budapest clinic, had written to a friend. The note, of course, was not sent on.

72 Svetlin, op. cit., note 1 above, p. 28.

73 "Bipolar disorder" is the currently accepted term for manic-depressive disease. See American Psychiatric Association, Diagnostic and statistical manual of mental disorders, (third edition-revised): DSM-III-R, Washington, APA, 1987, pp. 225-8.

74 Svetlin's diagnosis of case no. 275, for example, a non-Jewish male of 26, was "Circuläre Form der Geistesstörung (melanch. Stadium)", or of no. 228, a Jewish male of 20, "Verrücktheit (folie circulaire)". Earlier writers sometimes described it as "hysterisches Irresein" (hysterical insanity). See, for example, C. E. Louis Mayer, 'Menstruation im Zusammenhange mit psychischen Störungen', Beitr. Geburtsh. Gynäk., 1872, 1: 111-35, especially the case on p. 134. Michael Schmidt-Degenhard has offered a concise account of the evolution of the concept of manic-depressive disease in Melancholie und Depression, Stuttgart, Kohlhammer, 1983, especially pp. 52-6 and 86-106.

75 Flemming's actual statement was, that there is one case of mania for every five to six cases of depression, but further on he noted that mania almost always occurs in alternation with depression. Pathologie und Therapie der Psychosen, Berlin, 1859, p. 72.
} 


\section{Edward Shorter}

must have been considerable. Svetlin wrote in 1891 that, "The happy hopes of doctor and family that we are dealing with a pure form of mania are [often] terribly disappointed: the case turns out to be circular, with its gloomy prognosis."76

In several Svetlin patients with multiple admissions we see mania and melancholy alternating. Thus Helene M., a young Jewish woman of sixteen, from Galicia, was admitted in May 1884 with melancholia, and discharged well three months later. Then, four years after that, in July 1888, she was admitted again, this time with "mania periodica", and discharged well four months later. ${ }^{77}$ Of twelve patients having multiple admissions in which one of their diagnoses was melancholia, the other diagnosis was mania on two occasions. ${ }^{78}$ In overall terms, cases of mania and of manic-depression do not loom large against the huge mass of non-cyclical depressions. But for the historian of Vienna and of the Austro-Hungarian Empire they can nonetheless be of interest, as we shall see in a coming section.

Depression. Melancholia was most frequent diagnosis in the clinic, affecting one out of five patients. In these eighty-eight depressed patients, the average age at first admission to the clinic was 32.8. Now, the clinicians at Svetlin's establishment did not distinguish between major depression (Trübsinn, Melancholia) and minor depression (Verstimmtheit), but those at the Ober-Döbling clinic did. And at Ober-Döbling in the years 1875-91, major depression was almost four times as common as minor. ${ }^{79}$ So it might be fair to conclude that Svetlin's clinic was also dealing with highly depressed individuals. Indeed, many clinic directors indicated to what extent they were preoccupied with preventing their patients' suicide, a not unusual side-effect of depression. Only two suicides occurred in the Obersteiner clinic from 1875 to 1891 , in a total of 767 patients. And the Svetlin clinic, with a total of 468 patients, had only one suicide between 1879 and $1891 .^{80}$ Given that preventing the suicide of the depressed was a major purpose of both public and private nervous clinics, they achieved considerable success. ${ }^{81}$

Baroness X's encounter with depression was typical. There had been a history of the disease in her family, with her father's cousin a melancholic, her father's uncle

${ }^{76}$ Svetlin, op. cit., note 1 above, pp. 36-7.

${ }^{77}$ Svetlin case nos. 121 and 284.

${ }^{78}$ In the other ten patients, the second diagnosis was usually some form of "psychosis" (Verrücktheit), suggesting that the underlying problem might have been schizophrenia and not depression. Kaan describes one case, a Jewish woman of 31, from Lemberg, whose original diagnosis on the basis of her history was "circular insanity" ("circuläres Irresein"). See Svetlin, op. cit., note 1 above, pp. 103-4. On her second admission two years later she was deemed to have "Paranoia (folie raisonnante)". See Svetlin case nos. 359 and 504. What was her underlying problem? These diagnostic issues are difficult to untangle in today's patients, to say nothing of historically.

${ }^{79}$ Obersteiner, op. cit., note 30 above, pp. 55-7, tab. IV.

80 Ibid., p. 77. In the Svetlin clinic it was Johann J., 28 and married, a Catholic from Budapest transferred from the Fries clinic in Inzersdorf, who committed suicide on 30 December 1884 . He had been a melancholic. Svetlin no. 132. Svetlin omits him from his published tabulation of patients who had died in clinic.

${ }^{81}$ Between 1865 and 1906, in 69,000 patient-years at risk, the Niederösterreichische Landes-Irrenanstalt (the public asylum of Vienna and its hinterland) saw 21 suicides, a rate lower than that of the Svetlin clinic. Yet many of the public asylum's chronic patients were doubtless too demobilized psychically to undertake suicide, whereas the acute cases in a private clinic were more dangerous to themselves. See Karl Richter, 'Krankenbewegung der niederösterreichischen Landes-Irrenanstalt in Wien', Psychiat.-neurol.Wschr., 28 Sept. 1907, 8, pp. 227, 230. 


\section{A private nervous clinic in late nineteenth-century Vienna}

shooting himself, her brother suffering for years of "extreme nervousness". When she was forty-six her husband died, plunging her into a major depression. Five years after that her relatives started to believe her "psychically ill", because of her "hypochondriacal ideas", her extreme neurasthenia, and her excessive weight loss. In September 1896 her condition worsened. "She avoided company, could tolerate neither fresh air nor light, locked herself in her villa near Salzburg for months on end completely into a darkened room". It had then been seven years since her husband's death. In January 1897, she entered the Löw Sanatorium in Vienna, "following the advice of Richard Krafft von Ebing, and was treated by him for three months there. On April 9 she made a suicide attempt-wanting to plunge herself from the Imperial Bridge [Reichsbrücke], and was immediately brought to this clinic."

As she appeared for admission at the Svetlin clinic on 15 April 1897, accompanied by her relatives, she flung herself immediately upon the sofa in the office, "apparently completely exhausted, and complained about her 'fearful' condition. This commotion, this terrible commotion, and the noise that she hears, it swishes and swooshes [braust und saust] through her poor head. No one can imagine the torment she suffers." (The admitting physician mocked her a bit in his clinical notes.) Once in her room, she was tranquillized with opium, and all went well for about a month until the opium started to lose its effect, at which point she began lamenting, in "the stereotypical manner of a child", that the clinic's staff should just go ahead and kill her. "I beg you, go to the pharmacy and bring me poison immediately or a revolver." Or simply, "I'm just going to lie here. I'm going to lie here until I die", whereupon she would routinely turn to the doctor sitting next to her and ask him to bring her poison. Et cetera. We have followed the case sufficiently to gain an idea of depression in the clinic. $^{82}$ In the next section we see how it varied by sex and religion.

\section{DIAGNOSES: POSSIBLE SCHIZOPHRENIA AND HYSTERIA}

Possible schizophrenia. Given the distinctiveness of the clinical presentation of these diseases, late nineteenth-century diagnoses of neurosyphilis and mania are probably reliable. But other diagnostic terms in use today are more difficult to assign retroactively, especially in the absence of a clinical history. In the ledgers of the Svetlin clinic we often have nothing more than a single word to suggest the diagnosis. What historical assessments are possible on such slender evidence? The following section relies mainly on the logic of probability: a "psychosis" diagnosed in a young person is more likely to be schizophrenia than any other disorder, given the predominance of schizophrenia among the psychoses. Thus, among 20 young persons who have recently become "psychotic", the majority will probably be early schizophrenics, although we cannot say for certain whether any given individual among them has the disease. Because the concept of schizophrenia surfaced only at the turn of the century - the word itself only in $1911^{83}$ - the Svetlin doctors had no

\footnotetext{
82 Dossier in the archive of the Psychiatrisches Krankenhaus der Stadt Wien. She was discharged uncured from the Svetlin clinic two years later, at her own request.

${ }^{83}$ Emil Kraepelin discussed "dementia praecox" in Psychiatrie: ein Lehrbuch für Studierende und Ärzte, 5 th ed., Leipzig, 1896, p. 426-41. Eugen Bleuler coined the term "schizophrenia" in Dementia Praecox oder Gruppe der Schizophrenien, Leipzig, 1911: "Leider konnten wir uns der unangenehmen Aufgabe nicht
} 


\section{Edward Shorter}

special notion of "dementia in the young". Yet they were quite capable of diagnosing psychotic delusions, illusions, or hallucinations. I shall argue that the many cases of paranoia, psychosis (Verrücktheit, Wahnsinn), and dementia in young people in the clinic harboured a good deal of schizophrenia. (One would not think that first admissions for dementia in someone who had functioned well all his life until age 45 or so were suggestive of schizophrenia.) Thus there is nothing hard-and-fast about the category "possible schizophrenia" in table 4. I separate it out only to call the attention of other researchers to the potential importance of the subject. Yet it is interesting that 85 patients-one out of five-fall into this group.

What does a "possible schizophrenia" sound like? There was University-Professor $\mathrm{X}$, a 37-year-old Catholic from Lemberg in Galicia, who suffered from "hallucinatory mental disturbances". He was single. Dr W. Wobinski in Lemberg, the chief of the city hospital, had recommended his admission, and a brother and another doctor with a Polish surname from Vienna accompanied him to the Svetlin clinic on 27 October 1884. He was discharged "improved" half a year later. ${ }^{84}$

Or we have Louise T., thirty-three and Catholic from someplace in Bohemia. She had been living apart from her lawyer husband in Prague, and indeed had recently been a patient of Karl Ludwig Kahlbaum (who described in 1874 what would later be called "catatonic schizophrenia") at his private nervous clinic in Görlitz in Lower (Prussian) Silesia. When Louise T. was admitted to the Svetlin clinic in February 1891 , it was with the diagnosis of "paranoia persecutoria". She was discharged "improved" from the clinic six months later. ${ }^{85}$ Such reports are inadequate for a serious description of schizophrenia. This clustering of "paranoia", of dementia in people who were too young to have Alzeimer's disease, and of "psychosis" suggests we are skirting the fringes of schizophrenia, a disease which by that time had become very much a reality among the middle- and upper classes of the Austro-Hungarian Empire. $^{86}$

Hysteria. In Wilhelm Svetlin's clinic, hysteria was more a male than a female disease. Of the nine cases, five were men affected with "hysteria virilis". Now, because no case histories of these patients have survived, it is unclear if we are dealing with the "paralysed" arms and legs of conversion hysteria, with hysteria as a character disorder, or with the hysteria of Jean-Martin Charcot and its bizarre mixture of funny feelings in the throat, sudden patches of anaesthesia, and fits. Young Josef A., single, twenty-three and an engineer from Brünn, had "hysteria virilis". His two sisters and an aunt (who was married to a physician who lived near the clinic) recommended his admission, and after a two-week stay he was discharged "cured" on 17 June 1887.87

What did Josef A. have in common with the hundreds of young women with hysteria in other nervous clinics? Whereas only 3 per cent of the men in Karl von

\footnotetext{
entziehen, einen neuen Namen für die Krankheitsgruppe zu schmieden. Der bisherige ist zu unhandlich ... . Ich nenne die dementia praecox Schizophrenie ...." (pp. 4-5).

84 Svetlin case no. 148.

85 Svetlin case no. 437.

${ }^{86}$ Although schizophrenia and paranoia have many similarities, they are today considered separate diseases. See $D S M-I I I-R$, op. cit., note 73 above, pp. 197-8, for "schizophrenia-paranoid type", and pp. 199-201 for "delusional (paranoid) disorder".

${ }^{87}$ Svetlin case no. 235 .
} 


\section{A private nervous clinic in late nineteenth-century Vienna}

Ehrenwall's private clinic in Ahrweiler had hysteria, 17 per cent of the women received that diagnosis. ${ }^{88}$ At the Neufriedenheim clinic near Munich, 25 per cent of the male cases had "hysteria and other neuroses and nervous diseases", 41 per cent of the females. ${ }^{89}$ All this "hysteria" represented in likelihood a mixture of stress reactions in people with labile temperaments, undiagnosed multiple sclerosis, and early neurosyphilis, plus a variety of chronic invalidism today called "abnormal illness behaviour", "somatization disorder", or "Briquet's syndrome". 90 In any event, hysteria was not often seen in private clinics with extensive closed wards.

\section{WOMEN}

What in nervous disease was distinctive to women? As table 5 shows, mania and melancholia lay greatly in the domain of women. Together, those two diagnoses account for almost half ( 44 per cent) of the female cases, but for only one male patient in eight. The group "possible schizophrenia" affected a further quarter of the women patients. If we omit neurosyphilis, male shares of other disorders increase correspondingly. Yet there were only 26 depressed males, 62 depressed females, and juggling with percents should not distract us from explaining this difference.

Table 5: PERCENTAGES OF MEN AND WOMEN BY PSYCHIATRIC DIAGNOSIS: SVETLIN CLINIC, 1879-91

\section{Diagnosis}

Organic brain syndrome

Neurosyphilis

Alcoholism

Morphinism

Mania

Major depression

Possible schizophrenia

"Hysteria"

Other

Total

$$
\begin{aligned}
& \text { Percentage of men with } \\
& \text { that diagnosis }(N=264)
\end{aligned}
$$

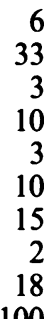

100
Percentage of women with that diagnosis $(\mathrm{N}=204)$

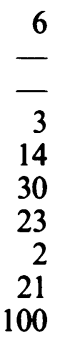

At what age were people admitted to the clinic for these disorders? (table 6). Here the only interesting differences emerge for mania and schizophrenia: women were much younger (by six years) than men when hospitalized for mania; men were somewhat younger when admitted for schizophrenia-like symptoms.

Table 6: AVERAGE AGE AT FIRST ADMISSION TO THE SVETLIN CLINIC FOR MEN AND WOMEN BY

\begin{tabular}{|c|c|c|}
\hline Diagnosis & Average age of men & Average age of women \\
\hline Morphinism & 34.5 & 32.0 \\
\hline Mania & 35.4 & 28.6 \\
\hline Major depression & 34.2 & 32.1 \\
\hline Possible schizophrenia & 30.0 & 34.1 \\
\hline
\end{tabular}
DIAGNOSIS, 1879-1891 


\section{Edward Shorter}

What do these statistics tell us about the lives of women? That they were more "manic" or "depressed" than men? Not necessarily: these are not prevalence statistics based on the number of cases per 1000 population at risk. ${ }^{91}$ They simply reflect differential admissions to a particular nervous clinic. The path from the first time the relatives noticed symptoms to the actual admission and handing over money to $\mathrm{Dr}$ Svetlin could be a long one. And along that road families could decide that: (a) the symptoms of mania are less tolerable in a woman than in a man; (b) that it is more therapeutic to institutionalize a "delicate" woman than a robust man because her nervous system needs more time to "recharge" (the storage-battery metaphor was a favourite in this domain). Also, women as patients might have been more inclined to seek admission. Maybe manic women went along more obligingly, while manic males struggled at the traces. These statistics are thus more suggestive of an agenda for investigation than a delineation of ready conclusions.

On one point, however, physicians who occupied themselves with nervous diseases seemed in substantial agreement: if they saw more women in their clinics it was partly because women responded more readily than men to the emotionality of family life, and bore more heavily as well its sentimental costs. Pierre Briquet, the Parisian clinician who wrote the classic study of hysteria, tried to explain why young women became hysterical (by which he designated much behaviour that would later be called mania, mild depression, and so forth): "A great danger results from the extreme solicitude of families. In life today, young women are surrounded by too much attentiveness and too much affection. Their upbringing ties them so closely to their mothers that they necessarily end up having the same sentiments as their mothers, thus making them more and more emotional. People have gotten into the habit of kissing young girls a lot, in order to give them, as one says, a good heart, and trying to develop in them a capacity for attachment. But this just increases all the more their hyper-affectivity, which is the mother of hysteria." ${ }^{92}$

So of course these middle-class young women would marry with the idea of contracting a sentimental union. It was at that point, in the eyes of Carl Max Brosius, whom we have met before as director of a nervous clinic in Bendorf on the Rhine, that adolescent "hysteria" turned to adult mania and depression, "One of the secrets of marriage concerns the genesis of those psychic disturbances that [we might call] 'the madness of married woman' ['Irresein der Ehefrauen'] . . . . It manifests itself as a prolonged sad mood with periodic insensate outbursts of extreme bitterness against the husband, in the absence of actual psychosis. For that reason cases are much commoner outside the clinic than inside." Brosius continued: "A married woman who is sexually dissatisfied, offended in her moral views, insulted in her vanity by her husband's neglect, and who sees herself given a lesser place and pushed aside, is capable of becoming the rashest of furies without actually being mentally ill." 93 The

\footnotetext{
91 True prevalence statistics do, however, demonstrate significantly higher rates of depression for women than men. A study of a random population sample in three American cities in 1981-2 showed that 2.3 to 4.4 men per 100 population had had a major depression, 4.9 to 8.7 women. Lee N. Robins, et al., 'Lifetime prevalence of specific psychiatric disorders in three sites', Arch. gen. Psychiat., 1984, 41: 949-58, esp. p. 954, tab. 3 .

92 [Pierre] Briquet, Traité clinique et thérapeutique de l'hystérie, Paris, 1859, p. 611.

93 Brosius, op. cit., note 18 above, pp. $6,8$.
} 


\section{A private nervous clinic in late nineteenth-century Vienna}

rashest of furies? Is this perhaps a description of much of the mania seen in the Svetlin clinic, and, when the fury had subsided, of the depression as well? Or could these unhappy marital circumstances unleash deeper biological lesions?

Although the Svetlin clinic's files give us little direct information about the family circumstances of the female patients, we are entitled to one inference: these women were deeply enmeshed in family life as they made their way to the Leonhardgasse in Vienna where the clinic was situated. Of all two hundred and four female patients, there was scarcely a handful about whom the family did not anxiously cluster, the father, husband or brother requesting admission, bringing the woman to the clinic and leaving addresses for news.

Among the exceptions we find poor Marie C., a 34-year-old Viennese, who seemed to have no relatives at all about her, although the name of a cousin was later written in as a billing address. Her diagnosis may have had something to do with this: paranoia. She died nineteen years later in the clinic, of tuberculosis. ${ }^{94}$ The relatives of Marie H., Catholic and thirty-four, from a small town in Styria, did seem a touch indifferent. If there was good news, they said, communicate it to Herr Alex H. back home. If bad news, tell the director of the clinic in Triest where she had previously stayed. Her diagnosis: mania. ${ }^{95}$ If nobody accompanied Jenny M., Jewish and thirty, to the clinic, it was probably because she was divorced. Her brother who lived near the clinic paid the fees, but no one came with her. ${ }^{96}$ But the saddest story, in this clinic full of sad stories, is that of Gitte Beile G., from Vilna in Lithuania, who at thirty-five had come to Vienna to give birth. She was Jewish, pregnant outside of wedlock, and perhaps for those reasons no friends' or relatives' names appear on her admission entry. She had suffered some kind of post-partum psychosis, and the head of the lying-in clinic requested her admission. She was discharged a month later, unwell, but at her own request. ${ }^{97}$ These cases stand out for their exceptionality. The clutch of relatives was the rule. It is clear that the female patients of the clinic were clasped very closely to the bosoms of their families. Whether this intimacy contributed to-or helped alleviate - their problems remains to be seen.

\section{JEWS}

The fact that many Jewish patients appear in these records does not mean that Jews had more mental illness. It is important to historians simply because, with ample numbers of Jewish patients to observe, we have a chance to see if particular patterns of illness existed among Jews. Thirty-two per cent of the patients at the Svetlin clinic were Jewish, a figure which is just about average for the private clinics. ${ }^{98}$ Yet the Svetlin clinic was not, to my knowledge, identified in any particular way as "Jewish", for if that had been the case, the Hungarian high aristocracy would never have ended up there. It was simply that the upper classes of the two religions mixed easily

94 Svetlin case no. 334

95 Svetlin case no. 435 .

96 Svetlin case no. 456 .

97 Svetlin case no. 250.

98 Thirty-four per cent of patients in the Ober-Döbling clinic were Jewish. In fact about half of all of Heinrich Obersteiner's female patients in the years 1875 to 1891 were Jewish. Obersteiner, op. cit., note 30 above, p. 55 . 
together. Many wealthy Jewish families found themselves able to pay the fees, and they bought the best care for their members. ${ }^{99}$ The non-Jewish patients of the clinic apparently accepted this without cavil, and the clinic offers in this respect something of a microcosm of relations between upper-class Jews and non-Jews in the Austrian empire before the turn of the century. ${ }^{100}$

The documents say that these Jews came from elsewhere. Eighty per cent of the 148 Jewish patients of the clinic had their "legal" residences, (where they were ultimately entitled to receive poor-relief), outside Austria, mainly in Moravia, Bohemia, Hungary, and Galicia. It was a characteristic of East European Jews to disparage their local doctors and seek out consultants in the West. Hermann Oppenheim, a distinguished Berlin neurologist who treated many East European Jews in his practice, observed, "[The Russian Jews] have a powerful confidence in doctors from abroad, up to the point of entirely forgetting that many diseases are incurable. They imagine that the malady will be-must be-cured in Berlin . . . . Of course this confidence is often the result of mistrust of the art of medicine in their own land."101 What Berlin represented for the Russian Jews, Vienna was to the Jews of the Habsburg Empire.

Svetlin's Jewish patients were a social mix. Of those who declared Vienna itself as their permanent residence, only a third were from the Leopoldstadt district, or "second district", which had become the figurative ghetto of Vienna. (The literal Jewish ghetto had been in the first district, which corresponded to the historic city of Vienna before the incorporation of suburbs began in 1859. $)^{102}$ Vienna had a long-resident, wealthy Jewish population in the first and third districts, and the clinic drew upon them. So on the face of it, only a few of Svetlin's Jewish patients were ghetto Jews.

Yet where one actually lived often differed from one's official place of residence. The clinic asked about the "most recent sojourn", and here many of the Jews legally resident elsewhere turned out to be living in Vienna, either with relatives or in their own quarters, quite often in the Leopoldstadt. They might well have been in the city

\footnotetext{
${ }^{99}$ Only two private nervous clincs specifically for Jews existed at this time in Central Europe. One was the "Privat-Asyl für gemüths- und nervenkranke Israeliten" in Bayreuth, which in 1880 had 21 patients. By 1906 it had abandoned its Jewish identification. The second was the "Israelitische Heil- und Pflegeanstalt für Nerven- und Gemüthskranke" in Sayn near Coblenz, with 25 beds in 1880. On these see Laehr, op. cit., note 4 above, editions of 1882 and 1907.

100 Elsa Bergmann had the following reminiscence of her mother, Bertha Fanta, in Prague. "My mother's social life was mainly with Christians and she had become friendly with some of the women of the best Aryan circles in playing cards. Of these best friends, the wife of a large industrialist and munitions-maker, Marie Poedel, asked her once, 'Bertha, since we're such good friends, I want you to tell me quite frankly and confidentially: Do the Jews really use the blood of Christians for Passover?"' Quoted from an unpublished manuscript in Wilma Iggers (ed.), Die Juden in Böhmen und Mähren: ein historisches Lesebuch, Munich, Beck, 1986, p. 286. It was only in 1897 that Arthur Schnitzler, who was Jewish, started commenting in his letters on growing anti-Semitism. Although he wrote the letter in question from Paris, the reference was meant generally. Therese Nickl and Heinrich Schnitzler (eds.), Arthur Schnitzler, Briefe, 1875-1912, Frankfurt-on-Main, Fischer, 1981, p. 316.

101 Hermann Oppenheim, 'Zur Psychopathologie und Nosologie der russisch-jüdischen Bevölkerung', $J$. Psychol. Neurol., 1908, 13: 1-9, quote on p. 4.

102 On the distribution and regional origins of the Viennese Jews, see Marsha L. Rozenblit, The Jews of Vienna, 1867-1914: assimilation and identity, Albany, State University of New York Press, 1983. Jews were about ten per cent of the population of Vienna around 1880.
} 


\section{A private nervous clinic in late nineteenth-century Vienna}

for many years. Thus, the Jews of the clinic represented an amalgam of those who had arrived long since from places like Moravia and Bohemia, solidly middle class, and those who were quite recently arrived from Galicia, just up from poverty.

Was there anything distinctive about Jewish psychiatric illness? This question has been debated for more than a century. ${ }^{103}$ The consensus is that Jews do not have more psychiatric morbidity than any other group in the population. ${ }^{104}$ What distinguishes East European Jews from non-Jews may be two things. First, the Jews may have sought help earlier and more frequently for symptoms that the patient or the family have already defined as "nervous" or "psychiatric". Wilhelm Svetlin wrote in 1884 that, "A further factor [in increasing the number of Jewish patients] is that the Jew generally is much more cautious [vorsorglich] about his health and not nearly as ill-disposed to admission to the clinic as are the members of other confessions." 105 Second, they may have been subject to a certain pattern of illness.

Observers have long been intrigued by the possibility that Jews, although they may not have mental illness in general more frequently, tend to suffer from distinctive mental illnesses. The frequently held belief of non-Jewish physicians, that Jews were more inclined to nervous illness, might be dismissed as anti-Semitism. ${ }^{106}$ Yet many Jewish physicians shared the same view, although they were less quick to ascribe Jewish mental illness to inbreeding and more inclined to point out the effects of economic desperation and cultural marginality. As Martin Engländer, a Jewish general practitioner in Vienna, wrote in 1902, using the idiom of his day, "The Jewish brain has been battling for centuries in a bitter struggle, right up until the time of emancipation, simply for a meagre, naked, existence." ${ }^{107}$ Hermann Oppenheim, also Jewish (a cousin of Karl Abraham), wrote of a "general Jewish predisposition to diseases of the nervous system, especially to the neuroses and psychoses". ${ }^{108}$ Rafael Becker, who earlier had been a staff physician at a private Swiss nervous clinic in Zihlschlacht in Thurgau Canton, asserted in 1919, on the basis of his own experience and statistics on asylum admissions, that, "Diseases of the mind and nervous system [Gemüth] are relatively more widespread among Jews than among the other peoples of Europe." ${ }^{109}$ S. Behrendt, director of the "Jewish Treatment and Nursing Center for Nervous Diseases" in Sayn near Coblenz, commented in 1912 on the distinctiveness of certain forms of mental illness among Jews. He found it significant that so many of

\footnotetext{
${ }^{103}$ For an overview see Sander L. Gilman, Difference and pathology: stereotypes of sexuality, race, and madness, Ithaca, Cornell University Press, 1985, pp. 150-62.

${ }^{104}$ See, for example, Benjamin Malzberg, 'Mental disease among Jews in New York State, 1960-1961', Acta psychiat. scand., 1973, 49:479-518. ". . . Jews had a lower overall rate of first admissions to mental hospitals than non-Jews". (p. 517).

${ }_{105}$ Svetlin, op. cit., note 14 above, p. 71.

106 As an example of the general medical belief in Jewish neuroticism, Wilhelm Erb, who called the Jews "eine neurotisch veranlagte Rasse", is often cited: Ueber die wachsende Nervosität unserer Zeit, Heidelberg, 1893, p. 19. For explicit anti-Semitism in non-Jewish physicians' discussions of Jewish mental illness see, for example, Johannes Lange, 'Ueber manisch-depressives Irresein bei Juden', Münchener med. Wschr., 21 Oct. 1921, 68: 1357-9.

${ }_{107}$ Martin Engländer, Die auffallend häufigen Krankheitserscheinungen der jüdischen Rasse, Vienna, 1902, p. 17.

${ }_{108}$ Oppenheim, op. cit., note 101 above, p. 1.

109 Rafael Becker, Die Nervosität bei den Juden: ein Beitrag zur Rassenpsychiatrie, Zurich, 1919, p. 8. At the time Becker was on the staff of the cantonal mental hospital in Königsfelden bei Brugg.
} 
his female patients - presumably all Jewish-were depressed. "Almost forty per cent of the women we admitted [over the period 1870 to 1910] suffered from mood disorders, the majority by far from simple melancholy or from circular depressive conditions [manic-depressive illness]."110

What do the Svetlin data contribute to this discussion? The percentage of Jews institutionalized for major depression was somewhat higher than that of non-Jews (table 7). That does not automatically mean that Jews generally are more depressed, for these are not prevalence data. Yet it indicates an area of curiosity.

Table 7: PERCENTAGES OF JEWS AND NON-JEWS BY DIAGNOSIS, SVETLIN CLINIC, 1879-91

Diagnosis

Organic brain syndrome

Neurosyphilis (men only)

Alcoholism

Morphinism

Mania

Major depression

Possible schizophrenia

"Hysteria"

Other

Total
Percentage of Jews with that diagnosis $(\mathrm{N}=148)$

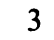

15

1

5

11

25

18

1

21

100
Percentage of non-Jews with that diagnosis $(\mathrm{N}=320)$

8
20
2
8
7
16
18
2
18
100

When one compares men and women of the same religion, more interesting differences appear. Almost half of the Jewish female patients were admitted for a major depression (table 8), only eight per cent of the Jewish men. Eighteen per cent of Jewish women came in for mania, four per cent of the Jewish men. Thus mania and depression, and their intersection of manic-depressive disorder, cluster among Jewish women, though the magnitude of the differences in the population are not revealed in these data.

Table 8: PERCENTAGES OF JEWISH MEN AND JEWISH WOMEN BY DIAGNOSIS, SVETLIN CLINIC, 1879-91

Diagnosis

Organic brain syndrome

Neurosyphilis (men only)

Alcoholism

Morphinism

Mania

Major depression

Possible schizophrenia

"Hysteria"

Other

Total
Percentage of Jewish men with that diagnosis $(\mathrm{N}=75)$

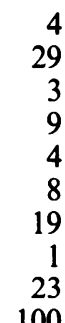

Percentage of Jewish women with that diagnosis $(\mathrm{N}=73)$

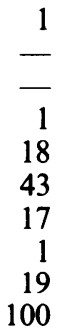

$110 \mathrm{~S}$. Behrendt and S. A. Rosenthal, 'Israelitische Heil- und Pflege-Anstalt für Nerven- und Gemütskranke Sayn bei Coblenz', in Bresler, op. cit., note 32 above, vol. 2, p. 432. "Die Frage, ob bei den Juden in der Verteilung der einzelnen Krankheitsformen andre Verhältnisse obwalten ist schon wiederholt aufgeworfen und von verschiedenen Forschern ... bearbeitet worden. Die von ihnen gefundenen Tatsachen werden im allgemeinen durch unsere Statistik bestätigt." (p. 431). 


\section{A private nervous clinic in late nineteenth-century Vienna}

As a rule, psychiatric diseases with a genetic component tend to begin earlier in life than diseases acquired from the environment. Here data on age at first admission do interesting service. Table 9 compares age at admission for Jews and non-Jews, suggesting that depression and some part of the schizophrenia complex may begin earlier in Jews.

Table 9: AVERAGE AGE AT FIRST ADMISSION TO THE SVETLIN CLINIC FOR JEWS AND NON-JEWS, BY DIAGNOSIS

Diagnosis

Morphinism

Mania

Major depression

Possible schizophrenia
Average age of Jews

35.0

30.7

28.6

28.8
Average age of non-Jews

33.7

29.9

35.7

33.8

It might be objected the figures mean merely that Jews seek help earlier for afflicted family members. Yet Jewish male patients with neurosyphilis were, at 46, older than non-Jewish male syphilis patients (age 43). Jewish male morphinists were also older.

Table 10 examines the age at onset for men and women, by religion. Although the numbers on which these averages rest are small, they merit further reflection. The disorders resembling "schizophrenia", for example, began in Jewish males around age twenty-five, in non-Jewish males not until thirty-three. Depression commenced considerably earlier for Jews of both sexes than for non-Jews: age twenty-nine for Jewish females, age thirty-six for non-Jewish females. Exactly the same difference, in depression, prevailed for Jewish and non-Jewish males.

Table 10: AVERAGE AGE AT FIRST ADMISSION TO THE SVETLIN CLINIC FOR MEN AND WOMEN BY RELIGION, 1879-91

\begin{tabular}{|c|c|c|c|c|}
\hline Diagnosis & Jewish men & Jewish women & $\begin{array}{l}\text { Non-Jewish } \\
\text { men }\end{array}$ & $\begin{array}{l}\text { Non-Jewish } \\
\text { women }\end{array}$ \\
\hline Mania & 33.7 & 30.0 & 36.3 & 27.5 \\
\hline Major depression & 29.0 & 28.6 & 35.8 & 35.7 \\
\hline Possible schizophrenia & 24.9 & 33.1 & 32.8 & 34.5 \\
\hline
\end{tabular}

Was it merely that Jews had more to be depressed about? That may have been part of it, for these well-to-do, upwardly-mobile East European Jews experienced tremendous stress as they struggled to establish themselves as social equals in commerce, medicine, and the state administration. ${ }^{11}$ But many surveys have shown that manic-depressive illness in particular clusters in Jewish women of East European origin. In a review of admissions to the university psychiatric clinic in Amsterdam between 1916 and 1940, F. Grewel found that 21 per cent of the Jewish women of East European (Ashkenazic) origin had manic-depressive illness, 11 per cent of the Jews of Mediterranean (Sephardic) origin. Of the non-Jewish women, 14 per cent had manic-depression. ${ }^{12}$ The vast

\footnotetext{
${ }^{111}$ A poignant evocation of how diffident ghetto life made one feel is Sigmund Mayer, Ein jüdischer Kaufmann, 1831 bis 1911, Leipzig, 1911, especially Part One.

112 Grewel, 'Psychiatric differences in Ashkenazim and Sephardim', Psychiat. Neurol. Neurochir., 1967, 70: 339-47, esp. p. 343, tab. 1. Both men and women were included among the Sephardim. Although data from other clinics are not broken down by sex, they show great over-representation of bipolar illness among
} 


\section{Edward Shorter}

majority ( 83 per cent) of the manic-depressive patients at the Talbieh Psychiatric Hospital in Jerusalem over the years 1949 to 1958 were from Europe and the Americas, and thus were for the most part of East European background. Two-thirds of them were women. ${ }^{113}$ In a nation-wide study of Israel done in 1958, 84 men per 100,000 population were hospitalized for psychosis, 101 women per 100,000. The female rate was found to be higher mainly because of manic-depressive disorders and several unspecified psychoses. ${ }^{14}$ From data on psychiatric hospitalizations in Jerusalem over the period 1969 to 1972, it was calculated that, on a lifetime basis, Ashkenazic Jews would have 35 cases of mood disorder (affective disorder) per 1000 population, Sephardic Jews only 15 per 1000 . In a sub-sample of 22 of these mood-disordered patients selected for a "chart review" (review of the case history), 45 per cent had manic-depression. ${ }^{115}$

This East European tropism towards depression and manic-depression has persisted in Jews who have gone to England and the United States, as well as Israel. In a study of 64 Jewish in-patients among 786 psychiatric in-patients in Harrow, Middlesex, between 1976 and 1978, the Jews had significantly more "affective psychoses and affective disorders", though the share of Jewish women in these was not higher than the share of non-Jewish women. ${ }^{116}$ In a study of 46 depressed Jewish patients, 41 normal Jewish patients, and a matched group of depressed and non-depressed Protestants, S. J. M. Fernando concluded that, as both Jews and non-Jews had equivalent family histories of the disease, the tendency to depression is passed on from generation to generation, and is unrelated to maternal overprotectiveness and the like. ${ }^{117}$ Finally, from New York have come two large studies, one of New York City in the period 1949-51, the other of New York State, 1959-61. In both of them, Jews had a hospitalization rate for manic depression more than twice that of non-Jews. ${ }^{118}$

\footnotetext{
Jews. Among 87,500 psychiatric patients in the German state of Bavaria, 1908-21, 5 per cent of the non-Jews had manic-depressive illness, 22 per cent of the Jews. Cited in Rafael Becker, 'Bibliographische Übersicht der Literatur aus dem Gebiet “Geisteserkrankungen bei den Juden"”, Allg. Z. Psychiat., 1932, 98: 241-76, citing, on p. 248, a study made in 1926 by M. J. Gutmann. Of the Jewish psychiatric patients in the municipal hospital of Lepaya (Latvia) in 1910-14, 46 per cent had "mania", 8 per cent of the Germans. Harald Siebert, 'Die Psychosen und Neurosen bei der Bevölkerung Kurlands', ibid., 1917, 73: 493-535, data from p. 500. The author noted that hospitalized Jews evidenced little melancholia-but only because the families kept such patients at home, a feat almost impossible with mania (p. 503).

113 Jozef P. Hes, 'Manic-depressive illness in Israel', Am. J. Psychiat., 1960, 116: 1082-6, esp. graph 1, p. 1083.

114 H. S. Halevi, 'Frequency of mental illness among Jews in Israel', Int. J. soc. Psychiat., 1963, 9: 268-82, esp. p. 273. Sephardim, by contrast, had higher rates of schizophrenia.

${ }_{11}$ Elliot S. Gershon and Jerome H. Liebowitz, 'Sociocultural and demographic correlates of affective disorders in Jerusalem', J. psychiat. Res., 1975, 12: 37-50, esp. p. 42, tab. 2, and p. 49.

116 Ruth S. Cooklin et al., 'The patterns of mental disorder in Jewish and non-Jewish admission to a district general hospital psychiatric unit: is manic-depressive illness a typically Jewish disorder', Psychol. Med., 1983, 13: 209-12. The authors concluded, "Manic-depressive illness could be the Jewish expression of mental disturbance, other ethnic groups 'choosing' different forms of expression." (p. 211).

${ }^{117}$ S. J. M. Fernando, 'Depressive illness in Jews and non-Jews', Br. J. Psychiat., 1966, 112: 991-6. His finding does not mean that the incidence of the disorder is equal in both Jews and non-Jews since he deliberately included as a "control group" a hand-selected population of non-Jewish manic-depressives.

118 Benjamin Malzberg, 'The distribution of mental disease according to religious affiliation in New York State, 1949-1951', Ment. Hyg., 1962, 46: 510-22, esp. p. 514. Malzberg, op. cit., note 104 above, p. 482.
} 


\section{A private nervous clinic in late nineteenth-century Vienna}

In February 1987, it became apparent why manic-depressive illness runs so strongly in families, and in certain groups in the population: it is caused by a defective gene. A marker for this gene was discovered on chromosome 11.19 Manic-depression accordingly becomes the first psychiatric illness to be demonstrated to have a genetic basis. Understanding nervous disease among Jews in the nineteenth century thus entails dealing with both the history of suffering that caused latent illness to become manifest, and with a very real biological basis of mental disorder.

What one learns from the admission register of this one private clinic-and from the world of "nervous disease" generally-is that the social history of mental and neurological illness in the nineteenth century is more complex than first meets the eye. Recent historians have become accustomed to reducing illness in various social groups to matters of "perception" and "labelling", almost as though real neurological and psychiatric affections did not exist, as though disease lay solely in the eyes of middle-class, male medical beholders. But in fact the historian must deal with the complex interaction between culture and biology. If nineteenth-century Jews believed themselves more subject to "nervousness" than other peoples, it was not just because, historically, they had suffered more, but because they obscurely but correctly perceived that indeed they were at greater risk of some disorders. If nineteenthcentury women found themselves often "melancholic", perhaps it was because their family circumstances permitted them to seek treatment more easily than men, but also because they were exposed to a hostile disease environment-in the form of pelvic contractions from rickets, iron-deficiency anaemia, infection and soft-tissue damage from childbirth-in ways that men were not. ${ }^{120}$ Scholars have long been aware of such interactions between culture and biology. But for social historians of medicine the next step is to attempt to describe the circumstances of their reciprocal action on each other.

\footnotetext{
119 Janice A. Egeland et al., 'Bipolar affective disorders linked to DNA markers on chromosome 11', Nature, 26 Feb. 1987, 325: 783-7. Further, Stephen Hodgkinson et al., 'Molecular genetic evidence of heterogeneity in manic depression', ibid., pp. 805-6. For a brief résumé see Gina Kolata, 'Manic-depression gene tied to chromosome 11', Science, 6 Mar. 1987, 235: 1139-40.

${ }^{120}$ See on this Shorter, A history of women's bodies, Harmondsworth, Penguin, 1983.
} 